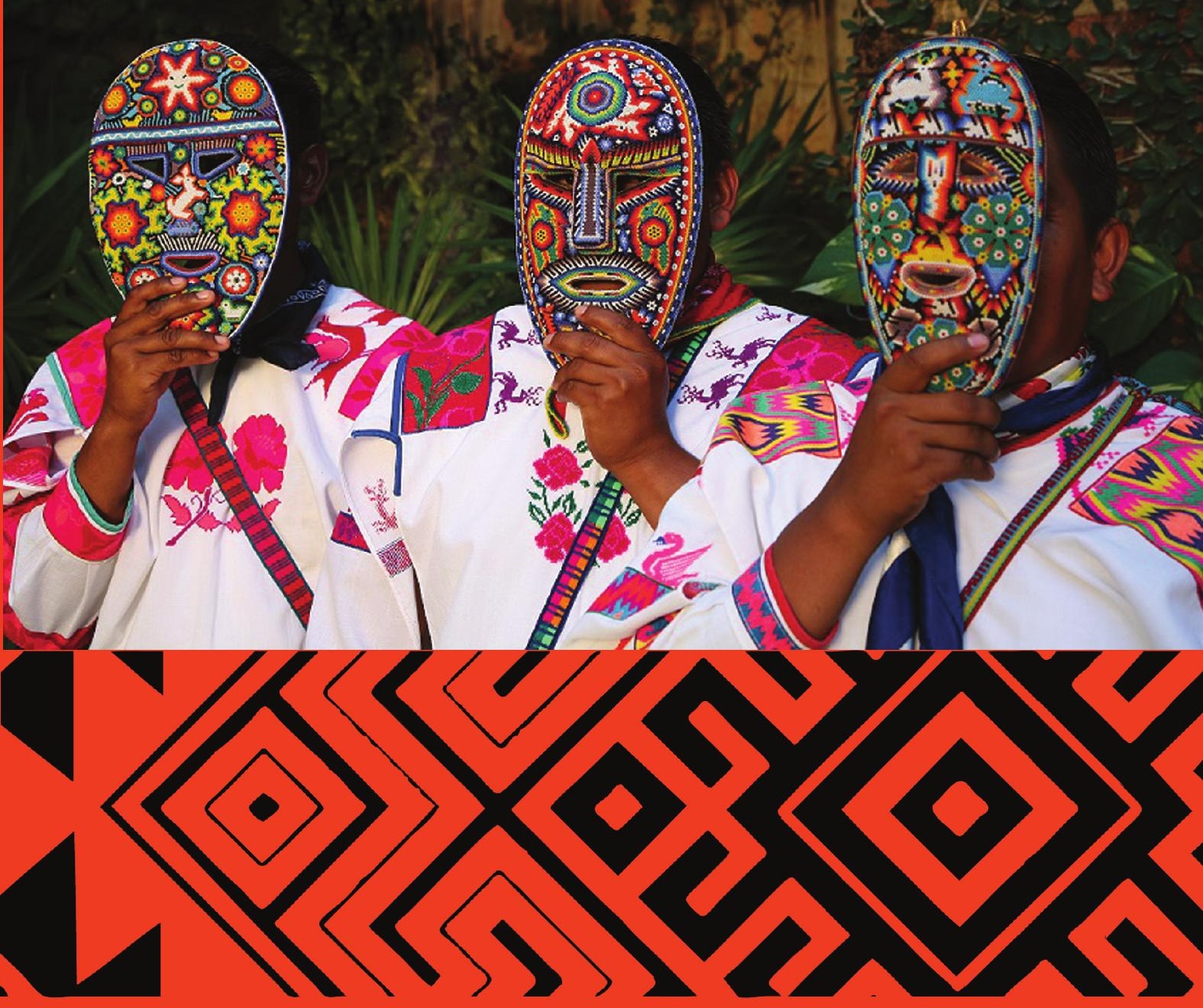

\title{
Consulta, territorios indios e información Manual de uso múltiple
}

Guillermo Padilla Rubiano / Nemesio J. Rodríguez Mitchell

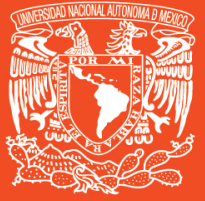





\section{Consulta, territorios indios e información Manual de uso múltiple}




\section{Coordinador José del Val}

UNIVERSIDAD NACIONAL AUTÓNOMA DE MÉXICO COORDINACIÓN DE HUMANIDADES

Programa Universitario de Estudios de la Diversidad Cultural y la Interculturalidad 


\title{
Consulta, territorios indios e información Manual de uso múltiple
}

\author{
Guillermo Padilla Rubiano \\ Nemesio J. Rodríguez Mitchell
}

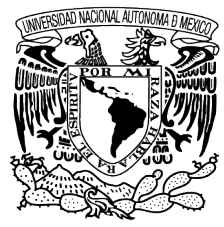

México 2016 
Padilla Rubiano, Guillermo, autor.

Consulta, territorios indios e información : manual de uso múltiple / Guillermo Padilla Rubiano, Nemesio J. Rodríguez Mitchell. -- Primera edición. -- México, D.F.: Universidad Nacional Autónoma de México, Programa Universitario de Estudios de la Diversidad Cultural y la Interculturalidad, 2016.

1 recurso en línea (94 páginas).

ISBN 978-607-02-9511-9

1. Pueblos indígenas - Condición jurídica, leyes, etc. - México.

2. Pueblos indígenas - México - Relaciones con el gobierno. I. Rodríguez Mitchell, Nemesio J., autor. II. Universidad Nacional Autónoma de México. Programa Universitario de Estudios de la Diversidad Cultural y la Interculturalidad. III. Título.

305.8002672-scdd21 Biblioteca Nacional de México

Primera edición: marzo de 2016.

D.R. ( ) 2016. Universidad Nacional Autónoma de México

Ciudad Universitaria, Delegación Coyoacán, C.P. 04510, México, D.F.

ISBN: 978-607-02-7706-1

Programa Universitario de Estudios de la Diversidad Cultural y la Interculturalidad

Av. Río Magdalena No. 100, Col. La Otra Banda, Deleg. Álvaro Obregón, C.P. 01090, México, D.F.

Oficina Oaxaca: Alameda de León No. 2 Altos, Centro Oaxaca de Juárez, C.P. 68000, Oaxaca, Oax.

Formación editorial: L.D.G. Gabriela I. Lavín Maciel.

Prohibida la reproducción total o parcial por cualquier medio, sin la autorización escrita del titular de los derechos patrimoniales.

Impreso y hecho en México 


\section{Índice}

Introducción general..............................................9

Parte I

Consulta y consentimiento libre, previo e informado: un instrumento.....13

Parte II

Consulta: ¿qué información es básica para tomar decisiones? 



\section{Introducción general}

En el tránsito del Programa Universitario México Nación Multicultural (PUMC-UNAM) al Programa Universitario de Estudios de la Diversidad Cultural y la Interculturalidad (PUIC-UNAM) se visualizó que uno, entre otros, de los temas focales referidos a los pueblos indios y similares de México y América Latina era el de la Consulta y el Consentimiento Libre, Previo e Informado (CCLPI), tanto en sus concepciones como en las aplicaciones. El contexto era y es el de la expansión del neoextractivismo en una perspectiva neocolonial, con el mercado suplantando y subordinando la política, los derechos reconocidos y el medio ambiente; y una lógica de respuesta del campo popular basado en la resistencia pasiva y activa, a los ordenamientos administrativos supranacionales, en defensa de territorios y sus recursos naturales, de concepciones propias y visiones del mundo diversas a los intentos de homogenización y desplazamiento compulsivo de poblaciones nativas completas. En el mismo contexto algunos de los Estados de América Latina proponían normas para la CCLPI, entre ellos México por la vía de la Comisión Nacional para el Desarrollo de los Pueblos Indígenas (CDI), sin consultar a los pueblos indios, evidenciando la poca o nula voluntad política de avanzar en la democracia intercultural que de palabra muchos declaraban. Es así como se encargó al 
abogado y antropólogo Guillermo Padilla el estudio que comprende la parte I del presente manual. Texto que es una aproximación jurídica y filosófica sobre las implicaciones que tiene la consulta y su necesaria utilización como parte de los derechos fundamentales de los pueblos indios y similares en los contextos nacionales. Hoy por hoy es un instrumento que podemos y debemos utilizar, en los contextos nacionales y supranacionales y Guillermo Padilla nos da los fundamentos, sus alcances e implicaciones.

La parte II, más cercana al suelo, encargada al antropólogo Nemesio J. Rodríguez, se refiere a la información que los pueblos deben requerir de los proyectos a empresarios y a las instituciones públicas para poder tomar decisiones. Decisiones que implican la vida presente y futura (1 ó 2 generaciones) de su diversidad biocultural. Se hacen preguntas básicas, según tipo de proyecto, como ejemplos, con el afán de que en cada caso concreto, los colectivos indios construyan el conjunto de requerimientos de información que necesitan y con los aliados que precisen.

Agradecemos al PUIC-UNAM, en tanto parte de una universidad pública y con el compromiso de abordar la comprensión de los grandes problemas nacionales aportando instrumentos de conocimiento para afrontarlos, que asuma la publicación de este manual. 
Cada autor es responsable de su parte y ambos del conjunto de este manual.

\section{Guillermo Padilla y Nemesio J. Rodríguez}

Noviembre, 2015 



\section{PARTE I}

\section{Consulta y consentimien to libre, previo e informado: un instrumento}

\section{Guillermo Padilla Rubiano PUIC-UNAM}

\section{Introducción}

El propósito de este texto es remarcar la importancia del derecho de los pueblos indígenas a la consulta y el consentimiento libre, previo e informado, en cuanto a que este derecho constituye un cambio de paradigma con múltiples implicaciones en las relaciones entre los pueblos indígenas y los Estados en América Latina. Este capítulo plantea los efectos jurídicos, políticos e institucionales del reto que los Estados han asumido en la aplicación y desarrollo de un sistema de consulta a pueblos indígenas que cumpla con los estándares internacionales, de manera que se garantice a los pueblos su derecho de participación, su integridad étnica, social, económica y cultural, así como asegurar su sobrevivencia con pleno derecho a mantenerse como grupos sociales diferenciados.

Debido a las posibles, y en algunos casos reales, afectaciones graves a los pueblos indígenas, el derecho a la consulta y el consentimiento libre, previo e informado 
o CCLPI, representa un derecho de fundamental relevancia para la protección de la diversidad étnica y cultural de la humanidad.

Por el incremento de grandes proyectos que impactan gravemente la naturaleza: minería a cielo abierto, proyectos de grandes hidroeléctricas, infraestructura, cambios en la vocación de los suelos, proyectos agrícolas de ingeniería genética, etcétera, que afectan territorios de comunidades étnicas y la gran diversidad que caracteriza a la mayoría de países latinoamericanos; la consulta previa es un tema de mucha importancia, que está generando considerable debate en todos los países del continente.

Este derecho, aunque tiene más de veinte años de haber sido introducido con el Convenio 169 de la Organización Internacional del Trabajo (OIT) aprobado en 1989 y ratificado por la casi totalidad de Estados latinoamericanos, es frecuentemente violado en casos de proyectos legislativos, de políticas públicas o de desarrollo de gran escala, tales como minas, presas, carreteras, obras de infraestructura, plantaciones o explotaciones forestales, parques eólicos, etc. En estos proyectos es común que los pueblos indígenas, como también los miembros de otras comunidades cubiertas por este derecho, sean excluidos del proceso de planificación y toma de decisiones. Las comunidades étnicas afectadas por proyectos corren el riesgo de ver alteradas sus fuentes de subsistencia, su idioma y cultura, que sus tierras 
sean dadas o confiscadas sin su consentimiento. Así mismo pueden ser víctimas de reasentamiento forzado sin que reciban una compensación adecuada. El resultado de esta exclusión puede ser altamente negativo para la protección de la diversidad étnica y cultural, tanto como para la democracia y la conservación de la naturaleza.

La razón de ser del derecho a la consulta previa es evitar estos abusos del poder, por medio de la apertura de espacios para que con la participación informada de las comunidades y pueblos se garantice, que su opinión sea tenida en cuenta a lo largo del proceso de consulta y que el resultado final sea el que se acuerde respetando las garantías mínimas que veremos a lo largo del presente trabajo.

El ejercicio de este derecho con el respeto, buena fe y dentro de los márgenes que configuran lo que aquí llamamos los estándares internacionales, formado fundamentalmente por las sentencias y recomendaciones del Sistema Interamericano de Derechos Humanos, que son la Corte Interamericana de Derechos Humanos (en adelante la Corte IDH) y la Comisión Interamericana de Derechos Humanos (CIDH); las recomendaciones de la Comisión de Expertos de la OIT, las declaraciones del Relator Especial sobre los Derechos de los Pueblos Indígenas de las Naciones Unidas y como referencia importante de derecho comparado, las sentencias de tribunales constitucionales y cortes supremas de justicia de países del con- 
tinente americano, está llevando a una transformación en las relaciones de los pueblos indígenas con el Estado, tanto como en la conformación de los Estados mismos.

Sin embargo, la falta de reglas claras, la legislación cambiante que introduce restricciones a los principios generales en el bloque de constitucionalidad y el poco compromiso político de las élites gobernantes con el mejoramiento de las condiciones de gobernanza, así como la desinformación y debilidad estructural de algunos sistemas de organización de parte de las comunidades, son dificultades que complican y retrasan los aportes que la aplicación de este derecho podría of recer a nuestras sociedades y Estados.

Con el fin de abonar a este cambio de paradigma, en este texto nos proponemos:

a) Propiciar una reflexión sobre un conjunto sistemático de principios y procedimientos a partir de los estándares internacionales vinculantes para los Estados, que faciliten al lector comprender la aplicación de este derecho como un mecanismo que fortalece el ejercicio de la ciudadanía, la participación y la democracia, con efectos al conjunto de la sociedad, por medio de la identificación de fases, pasos y procedimientos con particular efecto en una modificación sustantiva en la manera como los actores perciben al Estado, la ciudadanía y en últimas la democracia. 
b) Que el lector pueda constituirse, si lo desea, como un actor con capacidad de monitorear y acompañar críticamente el desarrollo de este derecho de conformidad con el marco legal que lo regula.

c) Contribuir a la resolución de casos que se le presenten en este campo en su tarea como funcionario judicial, funcionario público o en su labor como legislador.

Este texto ha sido diseñado una vez que la investigación de campo en comunidades afectadas por proyectos y en la acción de actualización y acompañamiento que hemos adelantado con poderes judiciales de varios países de América Latina, nos ha llevado a recabar lo que tanto jueces como funcionarios públicos, pueblos y comunidades afectadas consideran les hubiera sido útil saber en un comienzo, cuando tuvieron conocimiento sobre las medidas que las iban a afectar. El enfoque que le hemos dado está orientado para asistir a funcionarios estatales, organizaciones, autoridades propias de pueblos y sus asesores y a empresarios, con elementos útiles y prácticos para actuar invocando las reglas que los Estados han creado o ratificado. Es una herramienta práctica para facilitar el diálogo entre autoridades y representantes comunitarios, para facilitar la acción que se espera de funcionarios judiciales que tienen conocimiento y se espera tomen decisiones al respecto y para desarrolladores de proyectos, sean estos empresarios privados o 
instituciones of iciales nacionales o internacionales.

La consulta previa, libre informada es un derecho de origen internacional, que al ser parte de un convenio de derechos humanos (el Convenio 169), forma parte del bloque constitucional que limita el poder discrecional del Estado por medio del diálogo, la negociación, el acuerdo y el consentimiento de las comunidades y pueblos étnicos, también la "consulta contribuye a la protección de los derechos de los pueblos indígenas cuando entran en riesgo frente a las demandas y los requerimientos de sociedades numéricamente mayoritarias, y con mayor poder de decisión en las esferas de lo público y lo privado".

El reconocimiento del derecho a la Consulta y el Consentimiento constituye parte de un nuevo paradigma en las relaciones con los pueblos indígenas, por el que el Estado tiene la obligación de garantizar que la opinión de comunidades afectadas por proyectos sea tomada en cuenta, con diferentes niveles de obligatoriedad, según el tipo de afectación que la iniciativa pueda generar.

Como quedó dicho, el origen de este derecho se encuentra en el Convenio 169 de la OIT, pero aun en países que no lo han ratificado como Panamá y El Sal-

Conclusión del conversatorio institucional sobre consulta previa, Oficina en Colombia del Alto Comisionado de las Naciones Unidas para los Derechos Humanos (OACNUDH), marzo de 2008. Citado en El Derecho de los Pueblos Indígenas a la Consulta Previa, Libre e Informada. Una guía de información y reflexión para su aplicación desde la perspectiva de los Derechos Humanos, p. 16, http://www.acnur.org/t3/fileadmin/Documentos/Publicaciones/2011/7602.pdf?view=1 
vador, por su asociación a la Organización de los Estados Americanos, son también vinculantes las sentencias de la Corte IDH referidas a este derecho de conformidad con la interpretación que ella ha hecho sobre la base de derechos contemplados en la Convención Americana sobre Derechos Humanos.

El reconocimiento y protección de la diversidad étnica y cultural es un mandato constitucional en todos los órdenes jurídicos de los Estados de América Latina. Pero la importancia del derecho a la consulta va más allá de la órbita legal pues, como lo ha demostrado la experiencia en Colombia, Ecuador, Belice y Paraguay, por mencionar sólo algunos países donde la práctica de este derecho ha tenido impactos más allá de lo puramente mercantil, su trascendencia tiene que ver con la conservación de condiciones culturales que garanticen la continuidad de la vida misma en el planeta.

La hermenéutica diatópica, como lo sugiere Boaventura de Sousa Santos, entendida como la posibilidad de dialogar e interactuar con un pie en una cultura y otro en la restante, nos invita a buscar cómo movernos por diversas interpretaciones y sistemas simbólicos, poder entender la importancia de cada expresión cultural, como un camino hacia la ampliación de la conciencia de la incompletud de toda cultura (de Sousa Santos, 2010), un paso necesario para superar el lastre de la colonialidad que, con el peso de la razón, no nos permite abarcar la totalidad de 
la existencia. El diálogo intercultural facilita tener una perspectiva más amplia y encontrar argumentos y explicaciones que de otra forma no nos plantearíamos.

Otra razón de ser del derecho a la consulta es proteger la subsistencia de comunidades como grupos sociales diferenciados. Con este fin este derecho plantea que las decisiones legislativas y administrativas que las afecten deben haber sido fruto de un consenso generado de manera libre, previa e informada manifestado en un proceso participativo adelantado con transparencia y de buenafe.

Con frecuencia es posible que las leyes nacionales o la práctica administrativa, modifiquen la forma en que pueda ejercerse la consulta previa. Es importante, que las comunidades afectadas por proyectos busquen asesoramiento acerca de las leyes nacionales de sus respectivos países y encuentren la manera de hacer exigibles sus derechos, como los derivados de convenios internacionales en materia de derechos humanos que tienen una jerarquía equivalente a la de la Constitución Nacional, de acuerdo con el llamado bloque de constitucionalidad.

Es muy importante que todos tengamos claro que los convenios y tratados internacionales en materia de derechos humanos, y el Convenio 169 es uno de ellos, tienen un nivel jerárquico superior al orden jurídico nacional, por lo tanto ningún Estado puede alegar razones de orden interno para no aplicar estos derechos. Sobre 
este punto el artículo 27 de la Convención de Viena (instrumento internacional sobre el derecho de los tratados) ha dispuesto: "El derecho interno y la observancia de los tratados. Una parte no podrá invocar las disposiciones de su derecho interno como justificación del incumplimiento de un tratado". 2

Remarcamos que la consulta es un proceso compuesto de varias fases, con características y condiciones que han sido identificadas por sentencias y resoluciones del Sistema Interamericano de Derechos Humanos y por sentencias de tribunales constitucionales y cortes supremas de justicia de varios países del continente.

A partir de estas caracterizaciones jurisprudenciales se establece que la consulta no es un acto administrativo donde se informa a los pueblos y comunidades sobre una iniciativa o proyecto, ni una suerte de consulta popular donde la población vota a favor o en contra de una iniciativa. Es un proceso de diálogo y negociación entre representantes de comunidades étnicas, empresarios y Estado, según corresponda a cada caso particular, donde cada parte debe ejercer como actor con igualdad de dignidad y derechos en un marco de conocimiento y respeto a reglas preestablecidas por el Estado de Derecho. Esta meta, aunque falta todavía mucho para lograrla y

2 Convención de Viena sobre el derecho de los tratados, U.N. Doc. A/CONF.39/27 (1969), 1155 U.N.T.S. 331, entró en vigor el 27 de enero de 1980. Viena, 23 de mayo de 1969, https://www.oas.org/dil/esp/Convencion_de_Viena_sobre_derecho_tratados_ Colombia.pdf 
consolidarla, en la mayoría si no en la totalidad de países del continente, ha sido un camino muy importante para ejercer la ciudadanía y fortalecer la democracia, en la medida que su ejercicio mejora los niveles de organización comunitaria, información y toma de conciencia sobre derechos y organización del Estado en negociaciones con éste y empresas.

La diversidad étnica y cultural, que es uno de los bienes jurídicos que se protege con este derecho, se deriva de la existencia histórica de formas diferentes de concepción y práctica de vida social, expresadas por comunidades como sujetos colectivos con autonomía, lo que implica: garantía de la libertad para que ellas apliquen sus propias normas y procedimientos dentro de su territorio, con la única limitante de respetar los derechos humanos y los derechos fundamentales; a tener su propia forma de gobierno y la propiedad colectiva de sus territorios y la naturaleza inalienable, imprescriptible e inembargable de éstos. ${ }^{3}$

\section{Base legal y derecho aplicable a la Consulta y el Consentimiento Libre, Previo e Informado}

Como ya quedó dicho su origen es el Convenio 169 de la OIT y fue desarrollado en la Declaración de Naciones

3 Corte Constitucional de Colombia, Sentencia T-652 de 1998. 
Unidas sobre los Derechos de los Pueblos Indígenas y forma parte del bloque de constitucionalidad. En efecto, a excepción de Brasil y Chile, la mayoría de los Estados latinoamericanos otorgan rango constitucional a los tratados de derechos humanos en sus ordenamientos jurídicos internos. Los efectos prácticos más importantes se traducen en la inaplicabilidad de las normas de derecho interno que contradigan disposiciones de tratados de los que el Estado concernido sea parte. ${ }^{4}$ En algunos casos es la misma Constitución, caso de las Constituciones de Bolivia, ${ }^{5}$ Colombia, ${ }^{6}$ Guatemala ${ }^{7}$ y México, ${ }^{8}$ la que establece el rango constitucional de esos tratados, mientras

4 Derecho a la consulta y al consentimiento previo, libre e informado en América Latina. Avances y desafíos para su implementación en Bolivia, Brasil, Chile, Colombia, Guatemala y Perú, Fundación para el Debido Proceso - OXFAM, Washington, 2015. http:// www.dplf.org/sites/default/files/informe_consulta_previa_2015_web-2.pdf

5 En efecto, la Constitución Política del Estado Plurinacional de Bolivia de 2009 establece en su artículo 410 que la "Constitución es la norma suprema del ordenamiento jurídico boliviano y goza de primacía frente a cualquier otra disposición normativa”; mientras que, de acuerdo al artículo 13.IV de la Constitución, los tratados que reconocen derechos humanos y que prohíben su limitación en Estados de excepción prevalecen en el ordenamiento interno. La Constitución boliviana dispone, además, en su artículo 13.IV que los derechos y deberes establecidos en la Constitución se interpretarán conforme a los tratados de derechos humanos ratificados por Bolivia. Constitución Política del Estado Plurinacional de Bolivia de 2009, artículos 410.II y 13.IV.

6 El artículo 93 de la Constitución colombiana de 1991 indica que los tratados de derechos humanos prevalecen en el ordenamiento interno. Lo anterior se refuerza con el papel que se ha otorgado a los tratados de derechos humanos en la interpretación de la Constitución, pues el mismo artículo 93 establece que los derechos y deberes de la Constitución se interpretarán de conformidad con los tratados de derechos humanos.

7 La Constitución Política de la República de Guatemala establece en su artículo 46 que, como principio general "en materia de derechos humanos, los tratados y convenciones aceptados y ratificados por Guatemala tienen preeminencia sobre el derecho interno". Constitución Política de la República de Guatemala de 1985, artículo 46.

8 Artículo lo. "En los Estados Unidos Mexicanos todas las personas gozarán de los derechos humanos reconocidos en esta Constitución y en los tratados internacionales de los que el Estado Mexicano sea parte, así como de las garantías para su protección[...]". Constitución Política de los Estados Unidos Mexicanos. 
en otros ello ha sido afirmado por las más altas instancias de la jurisdicción constitucional.

En Chile hay una diferente interpretación al respecto, entre la Corte Suprema de Justicia y el Tribunal Constitucional. El primero argumenta que los derechos fundamentales reconocidos en los instrumentos internacionales de derechos humanos ostentan rango constitucional, ${ }^{9}$ mientras que el Tribunal Constitucional, ha señalado que la lectura de las normas constitucionales referidas a los tratados internacionales "es suficiente para concluir que nuestro texto fundamental no contiene una mención explícita al rango normativo de los tratados internacionales, ni siquiera cuando éstos versan sobre derechos esenciales que emanan de la naturaleza humana". La posición asumida por el Tribunal Constitucional chileno consiste en que la jerarquía normativa de los tratados es inferior a la de la Carta Fundamental, pero superior a cualquiera otra norma jurídica. ${ }^{10}$

Según la interpretación del Supremo Tribunal Federal de Brasil, los tratados de derechos humanos rati-

9 Corte Suprema. "Caso Sandoval". Sentencia del 17 de noviembre de 2004, Rol 517-2004; "Caso Vásquez y otros". Sentencia del 13 de diciembre de 2006, Rol 559-2004; "Caso Rojas". Sentencia del 13 de marzo de 2007, Rol 3125-04, considerando 35; "Caso Rojo Espinoza". Sentencia del 18 de junio de 2008, Rol 2054-08, considerando 1; "Caso Zapata Reyes". Sentencia del 10 de mayo de 2007, Rol 3452-06, considerando 66; "Caso Gómez Aguilar". Sentencia del 24 de enero de 2008, Rol 1528-06, considerando 37. Estas sentencias han sido citadas en: Claudio Nash Rojas. Derecho Internacional de los Derechos Humanos en Chile. Recepción y aplicación en elámbito interno. Chile: Universidad de Chile. Facultad de Derecho, 2012. http://www.cdh.uchile.cl/media/publicaciones/pdf/91.pdf

10 Tribunal Constitucional. Sentencia del 9 de febrero de 2013, Rol 2387, considerando Duodécimo. Véase, asimismo, Tribunal Constitucional. Sentencia del 8 de abril de 2002, Rol No. 346 y Sentencia del 9 de agosto de 2009, Rol No. 1288. 
ficados por el Estado son jerárquicamente superiores a las leyes ordinarias pero inferiores a la Constitución Federal." Solamente aquellos tratados de derechos humanos que sean ratificados por el Congreso de la República bajo un quórum cualificado de tres quintos de los votos tanto en el Senado como en la Cámara de los Diputados tendrán rango jerárquico constitucional.

En lo que respecta a Perú, si bien la Constitución no dispone expresamente el rango de los tratados, el Tribunal Constitucional ha afirmado que los tratados sobre derechos humanos ${ }^{12}$ tienen rango constitucional, en particular el Convenio 169 de la OIT.13

En América Latina este derecho es el que más ha alcanzado relevancia y apropiación por parte de los pueblos y comunidades, en relación a la defensa de su autonomía, territorialidad y control de los recursos naturales en sus territorios, ha sido igualmente el vehículo más importante en el ejercicio de la ciudadanía. No obstante, en algunos países, ha tenido poco debate e implementación tanto a nivel normativo como jurisprudencial, por lo cual es fundamental recurrir al desarrollo que el derecho ha tenido a nivel internacional, para lo que aquí llamamos los estándares internacionales.

11 Supremo Tribunal Federal (STF). Julgamento do Recurso Extraordinário - RE 466.34315. Voto do Ministro Gilmar Mendes, Tribunal Pleno, julgamento em 3.12.2008, DJe de 5.6.2009. Disponible en http://www.stf. jus.br/imprensa/pdf/re466343.pdf

12 Tribunal Constitucional. Exp. No. 03343-2007-PA/TC. Lima. Jaime Hans Bustamante Johnson. Sentencia de 19 de febrero de 2009, párr. 31.

13 Tribunal Constitucional. Sentencia Exp. No. 03343-2007-PA/TC, f. j. 31. 
En el ámbito del Sistema Interamericano, a partir de las obligaciones de los países que forman parte de la Organización de Estados Americanos y han aceptado la jurisdicción de la Corte IDH, las obligaciones contenidas en la Declaración Americana de los Derechos y Deberes del Hombre y en la Convención Americana sobre Derechos Humanos, están supeditadas a la interpretación y recomendaciones del Sistema Interamericano, ambas la Comisión y la Corte Interamericana de Derechos $\mathrm{Hu}^{-}$ manos han desarrollado estándares específicos en la materia..$^{14}$

La CIDH se ha referido al derecho a la consulta a través de distintos mecanismos como informes de país, informes anuales, el sistema de peticiones y casos, y el mecanismo de medidas cautelares. La Corte Interamericana, por su parte, ha emitido desde Awas Tiwni vs. Nicaragua, varias sentencias que han marcado un derrotero fundamental sobre el derecho a la consulta, entre ellas se distinguen dos sentencias: Caso del Pueblo Saramaka vs. Surinam, y Caso del Pueblo Indígena Kichwa de Sarayaku vs. Ecuador, en ellas se explica y fundamentan bases sólidas sobre las obligaciones internacionales rela-

14 Puede encontrarse una sistematización de los pronunciamientos del Sistema Interamericano en: CIDH. Derechos de los pueblos indígenas y tribales sobre sus tierras ancestrales y recursos naturales. Normas y jurisprudencia del Sistema Interamericano de Derechos Humanos. OEA/Ser.L/V/II, Doc. 56/09, 30 de diciembre de 2009. Citado en Derecho a la consulta y al consentimiento previo, libre e informado en América Latina. Avances y desafíos para su implementación en Bolivia, Brasil, Chile, Colombia, Guatemala y Perú. Op. cit., p. 17. 
tivas a este derecho. La importancia que estas aportaciones han hecho es histórica, al sentar diversos precedentes para definir los alcances del derecho a la consulta y el consentimiento en casos específ icos. ${ }^{15}$

Los estándares internacionales han identificado temas, principios, definiciones, problemas, creando un marco referencial que facilita la identificación y concreción de este derecho y los mecanismos para su implementación.

La consulta forma parte del derecho a la autodeterminación de los pueblos indígenas y tribales, como lo dijo el Relator Especial de Naciones Unidas sobre los Derechos de los Pueblos Indígenas, el derecho a la consulta es: "un corolario de un gran número de derechos humanos aceptados universalmente, entre ellos el derecho a la integridad cultural, el derecho a la igualdad y el derecho a la propiedad [...]. De manera más fundamental, ese deber deriva del derecho primordial de los pueblos indígenas a la libre determinación y de los principios conexos de democracia y soberanía popular [...]. En consonancia con esos principios, el deber de los Estados de celebrar consultas con los pueblos indígenas en los procesos de decisiones que los afecten tienen por objeto poner fin al modelo histórico de exclusión del proceso de adopción de decisiones con el objeto de que en el futuro

15 Caso Sarayaku vs. Ecuador; Saramaka vs. Surinam; Moiwana vs. Surinam; Yatama vs. Nicaragua; Myagna (Sumo) Awas Tiwni vs. Nicaragua; entre otros. 
las decisiones importantes no se impongan a los pueblos indígenas y que éstos puedan prosperar como comunidades distintas en las tierras en que, por su cultura están arraigados". ${ }^{16}$

Igualmente, en el marco del sistema universal, los órganos de control de la aplicación de los tratados han emitido decisiones dotando de contenido específico a sus instrumentos respectivos, ${ }^{17}$ a lo que se suman los pronunciamientos de los procedimientos especiales y otros mecanismos de Naciones Unidas cuyo mandato se relaciona con los pueblos indígenas, como son el Relator Especial sobre los Derechos de los Pueblos Indígenas, el Mecanismo de Expertos sobre los Derechos de los Pueblos Indígenas y el Foro Permanente para las Cuestiones Indígenas (UNPFII), por sus siglas en inglés.

También se encuentra, desde la perspectiva del derecho a la participación política, en el artículo 23 de la Convención Americana sobre Derechos Humanos ${ }^{18}$ y en la Declaración Universal de Derechos Humanos;

16 ONU, Consejo de Derechos Humanos, Informe del Relator Especial sobre la situación de los derechos humanos y las libertades fundamentales de los indígenas, James Anaya. Doc. ONU/A/ HRC/12/34, 15 de julio del 2009, párr. 41. http://www2. ohchr.org/english/bodies/hrcouncil/docs/12session/A.HRC.12.34.Add.6_sp.pdf

17 Véase, por ejemplo, Naciones Unidas. Comité de Derechos Humanos. Comunicación No. 1457/2006, Poma vs. Perú, dictamen del 27 de marzo de 2009; Comité para la Eliminación de la Discriminación Racial. Recomendación general \# 23 (1997), sobre los pueblos indígenas; Comité de Derechos Económicos, Sociales y Culturales. Examen de los informes presentados por los Estados parte, de conformidad con los artículos 16 y 17 del Pacto. Observaciones finales sobre Colombia. E/C.12/1/Add.74, 6 de diciembre de 2001.

$18 \mathrm{CIDH}$, Derechos de los pueblos indígenas y tribales sobre sus tierras ancestrales y recursos naturales. Doc. OEA/ser.L/V.II/doc. 56, 30 de diciembre de 2009. 
el Pacto Internacional de Derechos Civiles y Políticos; el Pacto Internacional de Derechos Económicos, Sociales y Culturales y algunas convenciones fundamentales de distintos órganos de ONU, y de la interpretación que de este derecho ha hecho el Sistema Interamericano de Derechos Humanos, la Comisión IDH y la Corte IDH. Es importante remarcar que el derecho a la participación que se encuentra en estas normas citadas son relevantes en lo que respecta a la aplicación de los principios de la consulta a toda persona afectada por proyectos, sean o no indígenas.

Declaración de las Naciones Unidas sobre el Derecho al Desarrollo: Todos tienen el derecho al desarrollo. La sostenibilidad del mismo está ligada a la capacidad de las personas de controlar sus objetivos. La participación de la comunidad en proyectos que les afecten debe ser coherente con los principios subyacentes de la CCLPI. Los pueblos indígenas tienen derecho a la CCLPI según el artículo 32(2) de la Declaración sobre los Derechos de los Pueblos Indígenas de la ONU:"Los Estados celebrarán consultas y cooperarán de buena fe con los pueblos indígenas interesados por conducto de sus propias instituciones representativas a fin de obtener su consentimiento libre e informado antes de aprobar cualquier proyecto que afecte a sus tierras o territorios [...]. Los desarrolladores de proyectos deben proteger y respetarestos derechos y los principios afines en la totalidad de sus operaciones". 19

19 Citado en: Christina Hill, Serena Lillywhite y Michael Simon, Guía sobre el con 
Leyes nacionales: los derechos a la participación e información, incluyendo el derecho a la CCLPI están protegidos por las leyes nacionales de cada país. En Bolivia la Constitución Política en el art. 30.II.15 la incorpora como un derecho colectivo de las naciones y pueblos indígena originario campesinos, al señalar: "II. En el marco de la unidad del Estado y de acuerdo con esta Constitución las naciones y pueblos indígena originario campesinos gozan de los siguientes derechos: 15. A ser consultados mediante procedimientos apropiados, y en particular a través de sus instituciones, cada vez que se prevean medidas legislativas o administrativas susceptibles de afectarles. En este marco, se respetará y garantizará el derecho a la consulta previa obligatoria, realizada por el Estado, de buena fe y concertada, respecto a la explotación de los recursos naturales no renovables en el territorio que habitan", 20 disposición concordante con los arts. $352^{21}, 304.121$ y $403^{22}$ de la norma suprema. Sin em-

sentimiento libre, previo e informado, Oxfam Australia, junio 2010, p. 10. https:// www.nmbu.no/sites/default/files/pdfattachments/oaus-freepriorinformedconsentspanish-0910.pdf

20 Nueva Constitución Política del Estado Plurinacional de Bolivia. Versión of icial aprobada por la Asamblea Constituyente - 2007 y compatibilizada en el Honorable Congreso Nacional - 2008. http://www.consuladoboliviano.com.ar/portal/node/119

21 El artículo 352 también dispone que la consulta debe ser libre, previa e informada y que corresponda a toda "población afectada"; así "[.... En las naciones y pueblos indígenas originario campesinos, la consulta tendrá lugar respetando sus normas y procedimientos propios".

22 El art. 403 correspondiente al capítulo de Tierra y Territorio de la norma fundamental, refiere que: I. Se reconoce la integralidad del territorio indígena originario campesino, que incluye el derecho a la tierra, al uso y aprovechamiento exclusivo de los recursos naturales renovables en las condiciones determinadas por la ley; a la consulta previa e informada y a la participación en los beneficios por la explotación de los recursos naturales no renovables que se encuentran en sus territorios; la facultad de aplicar sus 
bargo este precepto constitucional al ser reglamentado por la Ley 026 de 2010, en el art. 39 señala: "La Consulta Previa es un mecanismo constitucional de democracia directa y participativa, convocada por el Estado Plurinacional de forma obligatoria con anterioridad a la toma de decisiones respecto a la realización de proyectos, obras o actividades relativas a la exploración de recursos naturales. La población involucrada participará en forma libre, previa e informada"; pero agrega que las conclusiones "[...] no tienen carácter vinculante, pero deberán ser considerados por las autoridades y representantes en los niveles de decisión que corresponda". ${ }^{23}$

Por lo que, esta ley, una de las primeras leyes en ser promulgada luego de la vigencia de la Constitución Boliviana, no contempla la consulta previa en su dimensión autonomista; es decir, como un derecho colectivo de las naciones y pueblos indígenas, que entre otros aspectos involucra el derecho de libre determinación, ${ }^{24}$ lo que en definitiva no sólo implica el respeto de las normas y procedimientos propios, sino pasa por el carácter vinculante de los acuerdos asumidos así como el consentimiento previo de las naciones originarias que hacen al Estado plurinacional y descolonizado.

normas propias, administrado por sus estructuras de representación y la definición de su desarrollo de acuerdo a sus criterios culturales y principios de convivencia armónica con la naturaleza. Los territorios indígena originario campesinos podrán estar compuestos por comunidades.

23 Gaceta of icial de Bolivia, Ley No. 026, 30 de junio de 2010, Ley del Régimen Electoral, pp. 14-15. http://pdba.georgetown.edu/Electoral/Bolivia/Ley26-2010.pdf

24 Establecido en los arts. 2 y 30.II.4 de la Constitución Boliviana. 
Además, de ubicar estas normas legales, es también importante establecer si hay decisiones judiciales que hayan resuelto casos en el pasado y que constituyen precedentes que pueden ser tomados en cuenta y que pueden ser muy útiles. Las sentencias de la Corte IDH que hayan resuelto casos nacionales son vinculantes para los Estados donde ocurrió el hecho, de manera que conocerlas y utilizarlas es imprescindible. Asimismo como ya se mencionó, si el proyecto recibe financiamiento de instituciones financieras internacionales las normas y directrices de estos son obligatorias para las empresas o instituciones que las ejecutan, así que es igualmente importante conocerlas e invocarlas.

Este principio legal está cubierto por tres tipos distintos de derecho, según su grado de obligatoriedad para el Estado:25

- Derecho duro, constituido por las leyes nacionales y tratados internacionales, vinculantes, y que son claramente obligatorias para los Estados;

- Derecho emergente cuya obligatoriedad es exigible para los Estados que son parte de los procesos donde se generan, pero que para otros constituye una referencia en virtud de la noción del margen de apreciación. ${ }^{26}$

25 César Rodríguez Garavito, La consulta previa a pueblos indígenas. Los estándares del derecho internacional, Bogotá: U. de los Andes, 2010.

26 Margen de maniobra de los Estados donde estos toman en cuenta variables culturales para cumplir los compromisos de los derechos humanos internacionalmente definidos. 
- Derecho blando, son las reglas operativas de organismos financieros internacionales cuya obligatoriedad está condicionada al tipo de relación específica que exista en cada caso.

Para la primera categoría en el contexto internacional están las normas expedidas por el sistema de las Naciones Unidas, el Convenio 169 de la OIT (1989) y los pronunciamientos de la Comisión de Expertos en Aplicación de Convenios y Recomendaciones de la OIT (CEACR), la Declaración de las Naciones Unidas sobre los Derechos de los Pueblos Indígenas adoptada por la Asamblea General de las Naciones Unidas en el 2007, el Pacto Internacional sobre Derechos Civiles y Políticos (PIDCP), los pronunciamientos emitidos por el Comité de Derechos Humanos de las Naciones Unidas (Comité de Derechos Humanos), el Comité para la Eliminación de la Discriminación Racial (CEDR), el Comité de Derechos Económicos, Sociales y Culturales (CDESC), las declaraciones of iciales del Relator Especial de las Naciones Unidas sobre los Derechos Humanos y las Libertades Fundamentales de los Pueblos Indígenas y las recomendaciones del Foro Permanente para Cuestiones Indígenas de las Naciones Unidas.

Entre las de derecho emergente están las fuentes de derecho regional sobre el tema, tales como los pronunciamientos, opiniones consultivas sentencias de la Corte Interamericana de Derechos Humanos y los pronuncia- 
mientos y recomendaciones de la Comisión Interamericana de Derechos Humanos, así como el Proyecto de Declaración Americana sobre los Derechos de los Pueblos Indígenas de la Organización de Estados Americanos.

En tercer lugar, el derecho blando, constituido por algunas directrices de organismos multilaterales como el Banco Mundial, el Banco Interamericano de Desarrollo u organismos financieros de países como la OPIC (Overseas Private Investment Corporation) del gobierno de los Estados Unidos, a pesar de no ser vinculantes para los Estados, por su carácter de derecho voluntario, emiten pronunciamientos que fijan pautas y estándares sobre consulta previa, sin distinguir si las comunidades afectadas son indígenas o no, que influyen en la decisión de otorgar préstamos y en general en las relaciones políticas y financieras con los Estados. Cuando se está frente a un litigio estas normas obligan a las empresas y gobiernos que han sido financiados por estas instituciones internacionales.

\section{Las comunidades étnicas y pueblos indígenas como sujetos titulares y no objetos de la interven- ción del Estado. Criterios subjetivos}

La consulta previa es entendida como el derecho que tienen las comunidades étnicas, ${ }^{27}$ esto es, los pueblos

27 Además de pueblos indígenas los pueblos tribales están también cobijados por el Convenio 169 de la OIT, de acuerdo al concepto tribal incorporado en el Convenio 
indígenas y tribales, a que el Estado consulte previamente a su adopción todas aquellas medidas legislativas o administrativas que sean susceptibles de afectarles directamente. El objetivo principal de este derecho es constituirse en un medio de protección y garantía de conservación de la identidad étnica y cultural de las comunidades y pueblos étnicos.

La CCLPI es un derecho específico de los pueblos indígenas y tribales, entendiéndose por tribal aquellas comunidades, que sin ser descendientes de las que existían previamente a la conquista y colonización europea, que son las indígenas, sus características sociales, culturales y económicas son diferentes a las de la comunidad nacional dominante, particularmente en razón a la relación especial existente con sus territorios ancestrales, y porque se regulan ellos mismos, al menos en forma parcial, a través de sus propias normas, costumbres y tradiciones. ${ }^{28}$

Para poder ubicar adecuadamente aquellos sujetos que están cobijados por este derecho debemos tener en cuenta un elemento objetivo, es decir, la existencia de rasgos culturales y sociales compartidos por los miembros del grupo, que los diferencien de los demás sectores sociales, y un elemento subjetivo, esto es, la existencia de

que dice: "A los pueblos tribales en países independientes, cuyas condiciones sociales, culturales y económicas les distingan de otros sectores de la colectividad nacional, y que estén regidos total o parcialmente por sus propias costumbres o tradiciones o por una legislación especial".

28 Sentencia de la Corte IDH, referida al pueblo de Saramaka vs. el Estado de Surinam. 
una identidad grupal que lleve a los individuos a asumirse como miembros de dicha colectividad. ${ }^{29}$

\section{III.1 Significado histórico y social}

La importancia de este derecho es esencialmente ético e involucra tanto el orden histórico, como el político y la justicia. En primer lugar, porque se aplica a pueblos históricamente excluidos en la construcción del Estadonación, los que aun siendo las primeras naciones y los que encarnan los elementos más importantes de la diversidad étnica y cultural del continente, no se les tuvo en cuenta más que para usurparles su tierra y riquezas, subalternizarlos y de esta manera hacerlos fácil presa de la explotación.

Con este derecho pasan a ser protagonistas de las decisiones administrativas y medidas legislativas que los afecten antes de que sean aplicadas y en algunos casos, cuando el impacto sea tal que ponga en riesgo su sobrevivencia, no es suficiente la consulta sino que se requiere su consentimiento.

De igual modo, y frente a gravísimos problemas que afectan a la humanidad en su conjunto como el cambio climático y la crisis ecológica global, es un acto de elemental justicia escuchar la opinión de pueblos que nunca dejaron de sacralizar la naturaleza en lugar de reducirla a sim-

29 Corte Constitucional de Colombia, Sentencias C-915 de 2010, C-169 de 2001. 
ple depósito de materias primas, como ocurre en múltiples escenarios en el planeta.

La consulta se ha venido constituyendo como un mecanismo hacia la restitución del derecho de los pueblos indígenas a la autonomía y la libre determinación, que les fue negado en el proceso de colonización. Primero porque les devuelve la condición política de pueblo, lo que significa la restitución del derecho de decisión y administración plena sobre sus territorios. Segundo porque transforma cualitativamente la concepción de soberanía del Estado basada en un poder único que radica en el "pueblo" compuesto por ciudadanos cuya opinión debe contar para los gobernantes; el Estado, al reconocer el derecho de libre determinación, se obliga a desarrollar una noción de soberanía negociada.

La consulta debe ser implementada en todos los casos en los que el Estado tome una medida legislativa o administrativa que afecte a un pueblo. ${ }^{30}$ En ese sentido, el espíritu de la consulta trabajado en el Convenio 169 de la Organización Internacional del Trabajo y profundizado en la Declaración de Naciones Unidas sobre los Derechos de los Pueblos Indígenas, no sugiere que haya materias exentas de ésta, todo lo contrario, formula que cuando

30 Artículo 6, Convenio 169 de la OIT, "Al aplicar las disposiciones del presente Convenio, los gobiernos deberán: (a) consultar a los pueblos interesados, mediante procedimientos apropiados y en particular a través de sus instituciones representativas, cada vez que se prevean medidas legislativas o administrativas susceptibles de afectarles directamente [...]". 
un pueblo está en condiciones de ser afectado por una política de Estado, éste debe participar en un proceso de consulta.

El derecho a la consulta y el consentimiento libre, previo e informado constituye un instrumento que permite poner sobre la mesa del debate donde se deciden proyectos, o acciones legislativas o administrativas, por medio de la participación informada de las comunidades susceptibles de salir afectadas, consideraciones que son fundamentales más allá de aspectos técnicos de ingeniería, evaluaciones economicistas de costo/beneficio o de cualquier otro orden, como en los casos que se han puesto a consideración.

Por sentido común y por derecho, todos estamos legitimados para tomar las decisiones sobre lo que ha de ocurrir a nuestra tierra y derechos. Este principio está protegido por normas internacionales, los denominados Pactos Internacionales de Derechos Humanos y convenciones que coinciden con lo establecido en el artículo segundo de la Declaración sobre la Concesión de la Independencia a los Países y Pueblos Coloniales: "Todos los pueblos tienen el derecho de libre determinación; en virtud de este derecho, determinan libremente su condición política y persiguen libremente su desarrollo económico, social y cultural". ${ }^{31}$

31 Aprobada por la resolución 1514 (XV) de la Asamblea General de las Naciones Unidas, el 14 de diciembre de 1960. http:/ / www.un.org/es/decolonization/declaration.shtml 


\section{III.2 Derecho a la consulta de población no indígena}

En el presente manual, cuyo énfasis son los pueblos indígenas y tribales, tomamos también en cuenta el derecho a proteger su tierra, recursos en ella y derechos fundamentales de cualquier comunidad que pueda ser afectada por proyectos, independientemente de que se trate de pueblos indígenas, tribales o no.

El principio pro homine que permea todo el derecho de los derechos humanos, señala que se debe acudir a la norma más favorable a la persona humana, aquellas más amplias, o a la interpretación más extensiva, cuando se trata de reconocer derechos protegidos y de la misma forma a la norma o a la interpretación más restringida cuando se trata de establecer restricciones permanentes al ejercicio de los derechos o su suspensión extraordinaria. ${ }^{32}$

El Pacto Internacional de Derechos Civiles y Políticos y la Convención Americana sobre Derechos Humanos y leyes nacionales, incorporan el principio pro homine a menudo traducido como principio propersona. A partir de este principio se cubre población no protegida por el Convenio 169, que como sabemos sólo

32 Mónica Pinto. "El principio pro homine. Criterios de hermenéutica y pautas para la regulación de los derechos humanos", en La aplicación de los tratados sobre derechos humanos por los tribunales locales, Los editores del Puerto, Argentina, 1997, pp. 163172. http://www.corteidh.or.cr/ta-blas/20185.pdf (on line), Programa de Naciones Unidas para el Desarrollo. Oficina de Venezuela. 
alude a pueblos indígenas y tribales, según este principio todas las personas están cubiertas por las mejores y más amplias garantías respecto a derechos básicos, incluso aquellos que están presentes en legislaciones de otros países, aunque no en la propia.

En razón de disposiciones de orden constitucional, convenios y tratados internacionales, toda comunidad afectada por un proyecto independientemente de su condición de indígena o tribal, tiene derecho a ser consultada y negociar en los procesos de toma de decisiones que les afecten. Las personas no indígenas afectadas por proyectos tienen el derecho a ser consultadas y negociar en los procesos de toma de decisiones de conformidad con los principios subyacentes del derecho a la CCLPI. El Pacto Internacional sobre Derechos Civiles y Políticos (PIDCP), firmado y ratificado por prácticamente la totalidad de países del continente, que protege entre otros, los derechos a la integridad cultural y física y a una participación significativa de los interesados en las decisiones que los afecten, prevé, en el párrafo 3, del artículo 2, que compete a cada uno de los Estados partes en el Pacto garantizar que: "Toda persona cuyos derechos o libertades reconocidos en el presente Pacto hayan sido violados podrá interponer un recurso ef ectivo, aun cuando tal violación hubiera sido cometida por personas que 
actuaban en ejercicio de sus funciones oficiales [...]". ${ }^{33}$ Así mismo dispone en su artículo 5.1. Que: "Ninguna disposición del presente Pacto podrá ser interpretada en el sentido de conceder derecho alguno a un Estado, grupo o individuo para emprender actividades o realizar actos encaminados a la destrucción de cualquiera de los derechos y libertades reconocidos en el Pacto o a su limitación en mayor medida que la prevista en él. 2. No podrá admitirse restricción o menoscabo de ninguno de los derechos humanos fundamentales reconocidos o vigentes en un Estado Parte en virtud de leyes, convenciones, reglamentos o costumbres, so pretexto de que el presente Pacto no los reconoce o los reconoce en menor grado." 34

El derecho a la información específicamente relacionada con la cuestión ambiental también encuentra respaldo en otras normas y principios del derecho internacional ambiental y son aplicables a todas las personas y comunidades sin distinción. El derecho de acceso a la información y la participación de la sociedad en las decisiones ambientales son principios que han inspirado cambios a la legislación ambiental existente y/o a la adopción de nuevas normas en varios países, principalmente desde la década de los noventas en adelante. Esos

33 Pacto Internacional de Derechos Civiles y Políticos. Adoptado y abierto a la firma, ratificación y adhesión por la Asamblea General en su resolución 2200 A (XXI), del 16 de diciembre de 1966. Entrada en vigor: 23 de marzo de 1976, http://www.ohchr. org/SP/Professionalinterest/Pages/CCPR.aspx

34 Ibídem. 
cambios se deben en gran parte a la Carta de Principios sobre Medio Ambiente y Desarrollo aprobada en el ámbito de la Cumbre de la Tierra, que se llevó a cabo en Río de Janeiro en 1992.

Cualquier comunidad afectada por un proyecto debe poder ejercer sus derechos, participando en forma efectiva en la toma de decisiones y las negociaciones. Cuando una comunidad no indígena es afectada en un proyecto, su derecho a oponerse y negociar está protegido por varios cuerpos legales de origen internacional. El Convenio sobre Diversidad Biológica, por ejemplo, conocido como la Declaración de Río sobre el Medio Ambiente y el Desarrollo, ratificado por 178 países en 1992, donde la totalidad de los países latinoamericanos lo suscribieron, se compromete a los Estados a promover la participación social frente a cualquier asunto que afecte la naturaleza y el medio ambiente; incluye disposiciones en el sentido que todas las comunidades tienen el derecho a solicitar información al Estado o los desarrolladores de la iniciativa que dé lugar a este derecho, obras, actos administrativos o legislativos. En este sentido pueden llevar a cabo discusiones en el seno de su comunidad, buscar asesoramiento independiente, tener una comunicación continua con los desarrolladores del proyecto. Descubrir quién lo financia y desarrolla, quién lo planeó. Adelantar negociaciones con los desarrolladores del proyecto y el Estado y tomar decisiones en forma comunitaria. 
Dice el Principio 10: "El mejor modo de tratar las cuestiones ambientales es con la participación de todos los ciudadanos interesados, en el nivel que corresponda. En el plano nacional, toda persona deberá tener acceso adecuado a la información sobre el medio ambiente de que dispongan las autoridades públicas, incluida la información sobre los materiales y las actividades que encierran peligro en sus comunidades, así como la oportunidad de participar en los procesos de adopción de decisiones. Los Estados deberán facilitar y fomentar la sensibilización y la participación de la población poniendo la información a disposición de todos. Deberá proporcionarse acceso efectivo a los procedimientos judiciales y administrativos, entre éstos el resarcimiento de daños y los recursos pertinentes". ${ }^{35}$

En el caso particular del papel de la Corte IDH, en el ejercicio de su jurisdicción contenciosa, debemos recordar que ella está obligada a observar las disposiciones de la Convención Americana, interpretándolas conforme a las reglas que ese mismo instrumento previene y a las demás que pudieran ser invocadas conforme al régimen jurídico de los tratados internacionales, que figuran en la Convención de Viena sobre el derecho de los tratados. Sobre esto ha dicho la Corte: “[...]. Igualmente, ha de tener en cuenta el principio de interpretación que obliga

35 Declaración de Río sobre el Medio Ambiente y el Desarrollo, ONU, 14 de junio de 1992. Principio 10. http://www.un.org/spanish/esa/sustdev/agenda2l/riodeclaration.htm 
a considerar el objeto y fin de los tratados (artículo 31.1 de la Convención de Viena), al que infra se hace referencia, y la regla pro homine, inherente al derecho internacional de los derechos humanos -frecuentemente invocado en la jurisprudencia de la Corte-, que conduce a la mayor y mejor protección de las personas, con el propósito último de preservar la dignidad, asegurar los derechos fundamentales y alentar el desarrollo de los seres humanos". ${ }^{36}$

El Estado tiene la obligación de proveer información y asistencia en todos los casos. Cuando no sea posible encontrar quien responda de parte de los desarrolladores del proyecto, el internet es un buen recurso para encontrar información que pueda ser útil, sobre la empresa o los inversionistas.

\section{Criterios objetivos}

\section{IV.1 La afectación directa, como condición para el ejercicio de este derecho}

Según la Corte IDH con base en el Convenio 169 y la Declaración de Derechos de los Pueblos Indígenas de ONU, hay tres niveles de participación de los pueblos indíge-

36 Felipe Gómez Isa ( editor), El caso Awas Tingni contra Nicaragua. Nuevos horizontes para los derechos indígenas, Instituto de derechos humanos, Serie Derechos Humanos, vol. 11, Bilbao: Universidad de Deusto, 2003, p. 272. Comunidad Mayagna (Sumo) de Awas Tingni vs. Nicaragua, sentencia del 31 de agosto de 2001, voto razonado concurrente del juez Sergio García Ramírez, a la sentencia de fondo y reparaciones del caso "Comunidad Mayagna (Sumo) Awas Tingni", párr. 2. 
nas y tribales: el primero, general cuando las políticas y programas les conciernan, donde habrá el derecho a la participación; el segundo, específico, cuando las medidas administrativas o legislativas sean susceptibles de afectarlos directamente, frente al cual el Estado tiene el deber de la consulta previa; y el tercero, aún más particular, cuando la afectación sea de tal grado, en cuyo caso no es suficiente la consulta sino es necesario el consentimiento libre, previo e informado.

El criterio jurisprudencial dominante en Colombia respecto a la identificación de aquellos hechos administrativos, legislativos o de política pública que deben ser objeto de este derecho es que estos puedan tener una afectación directa sobre los derechos fundamentales de las comunidades o pueblos. En el caso de Ecuador esto se da cuando el proyecto o la medida legislativa afectan de forma sustancial los derechos colectivos de los pueblos indígenas y en particular lo relacionado con los recursos naturales, el derecho de la naturaleza y territorio. Y debe aplicarse este derecho a las comunidades, pueblos y nacionalidades indígenas que se encuentran asentados dentro del área de influencia de los bloques o áreas que serán objeto de los procesos licitatorios o de asignación. ${ }^{37}$

37 Ecuador. Decreto Ejecutivo No. 1247, Reglamento para la Ejecución de la Consulta Previa Libre e Informada en los Procesos de Licitación y Asignación de Áreas y Bloques Hidrocarburíferos, publicado en el Registro Oficial No. 759 del 2 de agosto de 2012. 
Se considera que hay una afectación directa cuando una medida adoptada por el Estado altera el estatus de la persona o de la comunidad, bien sea porque le impone restricciones o gravámenes, o, por el contrario, le confiere beneficios, ello independientemente de que tal efecto sea positivo o negativo, aspecto éste que debe ser, precisamente uno de los objetivos de la consulta. ${ }^{38}$

La idea de afectación directa se relaciona con la intromisión intolerable en las dinámicas económicas, sociales y culturales abrazadas por las comunidades como propias. ${ }^{39} \mathrm{Si}$ bien la afectación se examina en cada caso concreto,${ }^{40}$ lo que se evalúa es qué tanto incide la medida en la conformación de la identidad diferenciada del llamado pueblo étnico.

Algunos elementos útiles para determinar si se está frente a una afectación directa o no, son:

1. La existencia de una intervención que una medida determinada (política, plan o proyecto) presenta sobre cualquiera de los derechos de los pueblos indígenas.

2. El hecho de que la medida se oriente a desarrollar alguno de los derechos protegidos por el Convenio 169 de la OIT.

3. El análisis acerca de si la medida impone cargas o establece beneficios para la comunidad, de tal manera que

38 Corte Constitucional de Colombia, Sentencias C-750 de 2008, C-915 de 2010, C-941 de 2010, C-187 de 2011.

39 Corte Constitucional de Colombia, Sentencias T-382 de 2006, T-693 de 2011-13.

40 Corte Constitucional de Colombia, Sentencia T-745 de 2010. 
modifique su situación o posición jurídica.

4. La incidencia diferencial de la medida frente a los pueblos indígenas, en comparación con el resto de la población. ${ }^{41}$

Sin embargo, no todo lo concerniente a grupos étnicos implica una afectación directa. Podrían no ser objeto de consulta aquellas medidas que no regulan, interfieren o se predican de forma particular a su situación, como, por ejemplo, las normas dictadas para la generalidad de la población de un país. En este caso, el Estado debe propiciar espacios de participación, semejantes a los que gozan otros sectores de la población. ${ }^{42}$

\section{IV.2 Principios que orientan la implementación de este derecho}

La ONU ha identificado los siguientes principios para que un proceso de consulta pueda realizarse con pleno respeto a los estándares internacionales de derechos humanos: (i) universalidad, inalienabilidad e indivisibilidad; (ii) interdependencia e interrelación; (iii) no discriminación eigualdad; (iv) participación e inclusión; y (v) rendición de cuentas y Estado de derecho. ${ }^{43}$

${ }^{41}$ Corte Constitucional de Colombia, Sentencia T-376 de 2012.

42 Corte Constitucional de Colombia, Sentencia C-030 de 2008.

43 Ver: Grupo de Naciones Unidas para el Desarrollo, "Directrices sobre las cuestiones relativas a los pueblos indígenas", supra note 11, pp. 27-28. 
a) Universalidad, inalienabilidad e indivisibilidad: estos principios refieren al planteamiento integral que caracteriza la universalidad de los derechos humanos, su indivisibilidad, inalienabilidad e integralidad, esto es que no exista jerarquía entre los diferentes tipos de derechos, civiles, políticos, económicos, sociales, culturales o ambientales de que son titulares pueblos y comunidades étnicas, ya que todos son imprescindibles para una vida digna. De acuerdo con este principio el derecho a la consulta, se encuentra estrechamente vinculado con la realización de otros derechos humanos, tanto individuales como colectivos, de los pueblos indígenas, constituyendo una expresión concreta del derecho a la libre determinación y uno de los medios a través de los cuales pueden ejercer su derecho a participar y a definir su propio concepto de desarrollo.

Así mismo, el derecho a la consulta también funciona como un instrumento de protección de derechos de los pueblos y comunidades étnicas, pues abre la posibilidad para que mediante el diálogo con las autoridades y otros actores puedan advertir y establecer las condiciones necesarias para que los proyectos de desarrollo no terminen vulnerando su derecho a la tierra, territorio, recursos naturales y protección al medio ambiente, entre otros.

b) Interdependencia e interrelación: El derecho a expresar el consentimiento o lograr acuerdos y la o- 
bligación correlativa que tiene el Estado de consultar, constituyen un derecho sustantivo intrínsecamente relacionado con su derecho a la autonomía y libre determinación, lo cual también se vincula con la vigencia de otros derechos, como la participación política, a preservar y fortalecer sus culturas, lenguas e instituciones, a mantener sus territorios, así como a la salud, a la educación y al desarrollo, entre otros.

c) No discriminación, equidad e igualdad:el Estado debe garantizar el pleno ejercicio y goce de los derechos de los ciudadanos al interpretar y aplicar su normativa interna en condiciones de no discriminación y equidad. Por lo tanto, debe tomar en consideración las características propias, en particular la cultura, formas de organización social y el idioma, que identifican a los miembros de los pueblos y comunidades étnicas. Debe tomarse en cuenta la pertinencia cultural, es decir que toda la información que sea relevante se comunique a los representantes, con traductores de la confianza de los pueblos, de manera que estos comprendan y puedan trasmitir a sus representados de manera fidedigna y clara, de forma que se cumpla el objetivo constitucional que consiste en reconocer y proteger la diversidad étnica y cultural.

d) Participación e inclusión efectiva: La consulta previa no debe agotarse en un mero trámite formal, sino que debe concebirse como "un verdadero instrumento de 
participación", ${ }^{4}$ la consulta no debe entenderse como un fin, sino como un medio para alcanzar un diálogo entre el Estado y las comunidades étnicas que permita garantizar el respeto, ejercicio y reconocimiento de sus derechos colectivos.

La decisión final debe ser una consecuencia del proceso consultivo por lo que el Estado debe tener en cuenta la posición de las comunidades y cumplir con los requisitos esenciales del proceso, dado que el objeto de la consulta es garantizar su participación en la adopción de las decisiones que directamente les afecten. No satisfacen el deber de consulta previa las actividades que se limitan a simples trámites administrativos que tiendan a permitir el ejercicio del derecho a la defensa de las co- $^{-}$ munidades respecto a las medidas adoptadas, o esfuerzos extemporáneos por parte del gobierno nacional para cumplir con dicho procedimiento.

e) Rendición de cuentas, oportunidad y Estado de Derecho: Las comunidades deben participar de forma activa y efectiva con antelación a la adopción de la medida. Además, la participación ha de entenderse no sólo en la etapa previa del proceso, sino conforme a revisiones posteriores a corto, mediano y largo plazo, de acuerdo a lo dispuesto en la consulta inicial. La experiencia colom-

44 Informedel Comitéencargadode examinar la reclamación en la que sealega el incumplimiento por Brasil del Convenio sobre pueblos indígenas y tribales, 1989 (núm. 169), presentada en virtud del artículo 24 de la Constitución de la OIT por el Sindicato de Ingenieros del Distrito Federal (SENGE/DF). 
biana, el país donde más consultas previas se han llevado a cabo en los últimos 20 años, señala la importancia de establecer que el proceso de consulta debe estar precedido de un trámite pre-consultivo en el que se den acercamientos previos del interesado con las comunidades. Así lo señala la Corte Constitucional cuando afirma que "[...] (debe definirse) en forma preliminar con las autoridades de cada comunidad indígena o afrodescendiente, a través de un proceso pre-consultivo específicamente orientado a sentar las bases del procedimiento [...]". ${ }^{45}$

La consulta no puede estar limitada a un mero trámite formal e informativo. Las comunidades deben manifestar su punto de vista libremente, y participar de manera efectiva en la decisión final, bajo un ambiente de confianza y claridad del proceso. Perú, que ha sido el primer país de América Latina en aprobar una ley que reglamenta el derecho a la consulta, dice en su artículo 3 que el objetivo de la consulta es: "[...] alcanzar un acuerdo o consentimiento entre el Estado y los pueblos indígenas u originarios respecto a las medidas legislativas o administrativas que les afecten directamente, a través de un diálogo intercultural que garantice su inclusión en los procesos de toma de decisión del Estado y la adopción de medidas respetuosas de sus derechos colectivos". ${ }^{46}$

45 Corte Constitucional, sentencia T-737 de 2005, M.P. Álvaro Tafur Galvis. http:/ /www. corteconstitucional.gov.co/relatoria/2008/c-461-08.htm

${ }^{46}$ Ley de Derecho a la Consulta Previa a los Pueblos Indígenas u Originarios reconocido en el Convenio 169 de la Organización Internacional del Trabajo, Congreso de la 
"La Corte Interamericana en el caso Saramaka vs. Surinam ha establecido tres garantías o salvaguardas que debe respetar el Estado:

1.- Participación efectiva (consulta, participación y consentimiento previo, libre e informado).

2.- Beneficios (indemnizaciones y ganancias).

y 3.- Estudio previo de impacto social y ambiental.

130. [...] el Estado debe cumplir con las siguientes tres garantías: primero, el Estado debe asegurar la participación efectiva de los miembros del pueblo Saramaka, de conformidad con sus costumbres y tradiciones, en relación con todo plan de desarrollo, inversión, exploración o extracción (en adelante "plan de desarrollo o inversión")[...].124. [...] que se lleve a cabo dentro del territorio Saramaka. Segundo, el Estado debe garantizar que los miembros del pueblo Saramaka se beneficien razonablemente del plan que se lleve a cabo dentro de su territorio. Tercero, el Estado debe garantizar que no se emitirá ninguna concesión dentro del territorio Saramaka a menos y hasta que entidades independientes y técnicamente capaces, bajo la supervisión del Estado, realicen un estudio previo de impacto social y ambiental. Mediante estas salvaguardas se intenta preservar, proteger y garantizar la relación especial que los miembros del pueblo Saramaka tienen con su territorio, la cual a su vez, garantiza

República, Comisión de Constitución y Reglamento, Lima, Perú, 2011. 
su subsistencia como pueblo tribal". ${ }^{47}$

El Ministerio del Interior de Colombia incluye otros principios que caracterizan la consulta. ${ }^{48}$ Estos son:

f) No confrontación. La consulta no implica un proceso de rivalidad entre las autoridades, los empresarios y los grupos étnicos, es la oportunidad para que las comunidades participen en los proyectos, que con su pleno e informado consentimiento, se hayan de realizar en sus territorios. Se trata de un diálogo, donde considerando las asimetrías, el Estado debe idealmente resolver las mismas a partir de su supervisión, garantía y promoción de las comunidades respecto a las medidas adoptadas, o esfuerzos extemporáneos por parte del gobierno nacional para cumplir con dicho procedimiento.

g) Ponderación de intereses. Las partes deben evaluar los intereses en juego, en el campo económico, cultural, ecológico y otros órdenes. Sólo serán admisibles las restricciones a la autonomía de las comunidades cuando sea una medida necesaria para garantizar la seguridad interna e intereses de superior jerarquía y sea menos gravosa para la autonomía a que tienen derecho.

Un objetivo esencial de este derecho es constituirse en un medio de protección y garantía de conservación

47 "Principios mínimos para la aplicación de los derechos de participación, consulta previa y consentimiento previo, libre e informado", Instituto Internacional de Derecho y Sociedad, Lima, noviembre de 2011. http://www.derechoysociedad.org/IIDS/Documentos/PRINCIPIOS-MINIMOS_IIDS.pdf

48 Ministerio del Interior y de Justicia: La consulta previa a los pueblos indígenas y tribales: compendio de legislación, jurisprudencia y documentos de estudio, Bogotá, 2006. 
de la identidad étnica y cultural de las comunidades y pueblos étnicos. El reconocimiento y protección de la diversidad étnica y cultural es un mandato constitucional en todos los órdenes jurídicos de los Estados de América Latina.

\section{El proceso de Consulta y Consentimiento libre, previo e informado}

\section{V.1 ¿A partir de qué momento se debe implementar este derecho?}

La Corte Constitucional de Colombia ha establecido que deben ser consultadas antes de la adopción de las medidas legislativas o administrativas, como por ejemplo: la ejecución de los proyectos de explotación o aprovechamiento de recursos naturales, es decir, desde la etapa de estudios de planeación, para que las comunidades puedan influir en el proceso decisorio. Éstas tienen la posibilidad de revisar y poner de presente sus puntos de vista sobre la intervención no sólo de forma previa sino durante y después de la implementación de la obra, conforme a los tiempos previstos de revisión a corto, mediano y largo plazo en la consulta inicial. ${ }^{49}$

49 Corte Constitucional de Colombia, Sentencia T-129 de 2011. 


\section{V.2 ¿A quién corresponde la obligación de propi- ciar y monitorear la consulta previa?}

De acuerdo con la sentencia de la Corte IDH "pueblo de Sarayaku vs. Ecuador" es el Estado quien debe garantizar la realización plena de este derecho y no las empresas, mucho menos aquella con interés directo en la materia objeto de la consulta.

En México ante la ausencia de legislación secundaria que establezca, cómo, cuándo y a quién se hace la consulta, y ante la falta de directrices jurisdiccionales que suplan este vacío, es necesario recurrir a los estándares internacionales y a las provisiones de tribunales constitucionales de otros países de América Latina, que nos permitan entender el mecanismo a través del cual se debe cumplir con este derecho.

En el caso de Colombia es la Dirección de Consulta Previa del Ministerio del Interior, quien articula e impulsa la consulta previa con las comunidades étnicas. Las entidades territoriales (departamentos, distritos y municipios) también pueden efectuar procesos de consulta en su jurisdicción.

No obstante, en Colombia la autoridad ambiental, hoy la ANLA -Autoridad Nacional de Licencias Ambientales-, una vez se solicita la licencia ambiental o el establecimiento del Plan de Manejo Ambiental, debe comprobar la participación de las comunidades 
en la elaboración de estudio de impacto ambiental, o su no participación, y citar a la reunión de consulta previa para que ésta sea realizada dentro de los treinta (30) días siguientes al auto que así lo ordene..$^{50}$

Es importante recalcar que la consulta es un proceso compuesto de varias fases, con características y condiciones que han sido identificadas por sentencias y resoluciones del Sistema Interamericano de Derechos Humanos, recomendaciones del relator especial sobre los derechos de los pueblos indígenas de la ONU, del comité de expertos de la OIT y por sentencias de tribunales constitucionales y cortes supremas de justicia de varios países del continente.

A partir de las caracterizaciones jurisprudenciales se establece que la consulta no es un acto administrativo donde se informa a los pueblos y comunidades sobre una iniciativa o proyecto, ni una suerte de consulta popular donde la población vota a favor o en contra de una iniciativa. Es un proceso de diálogo y negociación donde cada parte debe ejercer como actor con igualdad de dignidad y derechos, en un marco de conocimiento y respeto a reglas preestablecidas por el Estado de Derecho. Esta meta aunque falta todavía mucho para lograrse y consolidarse, en la mayoría sino en la totalidad de países del continente, ha sido un camino muy importante para

50 Colombia, artículo 12 del Decreto 1320 de 1998. 
el fortalecimiento del ejercicio de la ciudadanía y el fortalecimiento de la democracia, a partir de la toma de conciencia de ser sujeto de derechos, comprender y evaluar la función del Estado, familiarizarse con los procedimientos por medio de los cuales se puede activar la acción del Estado a partir de dinamizar la independencia de los poderes públicos, como lo demuestra la experiencia documentada de las consultas llevadas a cabo en países latinoamericanos.

Los pueblos indígenas tienen el derecho de participar en cualquier decisión que afecte sus tierras, recursos o territorios, a ser consultados y que su opinión sea tenida en cuenta, ó a dar o negar su consentimiento libre, previo e informado, según sea el caso. Tienen el derecho de arribar a una decisión colectiva a través de procesos definidos y establecidos por ellos mismos, como ya vimos respecto a la pertinencia cultural.

Reclamar el respeto del derecho a la consulta y el consentimiento libre, previo e informado es una tarea que exige organización, investigación y asesoría. La consulta es un proceso continuo y las negociaciones pueden durar mucho tiempo. Las comunidades afectadas por proyectos deben estar en capacidad de exigir su participación en las negociaciones y de solicitar toda la información que sea relevante al proyecto o iniciativa.

Con frecuencia, estos derechos no son reconocidos automáticamente. Algunos gobiernos, empresas y finan- 
ciadoras muestran cierto progreso en lo referente al respeto de este derecho y cuentan con políticas y compromisos propios donde se obligan a aplicarlo. Sin embargo, para muchos empresarios y para el Estado mismo, la consulta sigue siendo algo que no implementan, porque lo desconocen o porque argumentan que todavía no hay una ley que lo haga viable, o bien porque lo ven como un obstáculo a lo que para ellos es una inversión o desarrollo importante.

Sin embargo las comunidades tienen el derecho a expresar su propia opinión y esta debe ser escuchada, debatida y tenida en cuenta. Además como lo ha dicho la Corte Constitucional colombiana, no porque una inversión sea de varios millones, es más importante que la protección de la diversidad étnica y cultural, es hora de superar que lo más grande es siempre mejor o más importante, el tiempo ecológico actual con los efectos dramáticos en términos de cambio climático, acidificación de los océanos y extinción de especies nos obliga a replantear la validez de esta asociación.

\section{V.3 ¿Cuándo la Consulta no es suficiente y se re- quiere el Consentimiento?}

El consentimiento es un derecho atribuible exclusivamente a las poblaciones indígenas y tribales y opera: 
1. Cuando el proyecto implique traslado de los pueblos indígenas de sus tierras tradicionales (Declaración de Naciones Unidas sobre los derechos de los pueblos indígenas, artículo 10).

2. Cuando el proyecto implique el almacenamiento o eliminación de materiales peligrosos en sus territorios (Declaración de Naciones Unidas sobre los derechos de los pueblos indígenas, artículo 29.2).

3. Cuando se trate de planes de desarrollo o de inversión a gran escala que pudieran tener un impacto mayor en los territorios indígenas (Corte IDH, Caso del Pueblo de Saramaka vs. Surinam. Excepciones Preliminares, Fondo, Reparaciones y Costas, párr. 133).

4. Cuando se trate de actividades de extracción de recursos naturales en territorios indígenas que tengan impactos sociales, culturales y ambientales significativos (Anaya, 2010).

En declaración pública del Relator Especial sobre los Derechos Humanos y Libertades Fundamentales de los pueblos Indígenas de Naciones Unidas, James Anaya, sobre la Ley del derecho a la consulta previa a los pueblos indígenas u originarios reconocido en el Convenio No. 169 de la Organización Internacional de Trabajo aprobada por el Congreso de la República del Perú, el 7 de julio de 2010, agregó este último punto, el que refiere a impactos significativos, lo que ocurre cuando las iniciativas o proyectos, en particular actividades de extracción 
de recursos amenacen u ocasionen 1 . La pérdida de territorios y tierra tradicional; 2. El desalojo; 3. La migración; 4. El posible reasentamiento; 5 . El agotamiento de recursos necesarios para la subsistencia física y cultural; 6. La destrucción y contaminación del ambiente tradicional; 7. La desorganización social y comunitaria; 8. Los negativos impactos sanitarios y nutricionales de larga duración; 9. El abuso y la violencia.

El Relator Especial de la ONU ha precisado en esta línea que: "[...] en todos los casos en que una medida propuesta afecte los intereses particulares de los pueblos indígenas, la obtención de su consentimiento deberá ser, en cierta medida, una finalidad de las consultas. (...) esta exigencia no confiere a los pueblos indígenas un 'poder de veto' sino que, más bien, establece la necesidad de elaborar procedimientos de consulta con el fin de hacer todo lo posible por lograr el consenso de todas las partes interesadas. (...) Esos principios [de consulta y consentimiento] han sido concebidos para crear un diálogo en que los Estados y los pueblos indígenas puedan trabajar de buena fe con miras al logro del consenso y procuren seriamente llegar a un acuerdo satisfactorio. (...) el deber de los Estados de celebrar consultas con los pueblos indígenas y los principios conexos ha surgido para poner fin a modelos históricos de decisiones que se han impuesto a los pueblos indígenas y a condiciones de vida que han amenazado su supervivencia. Al mismo tiempo, los prin- 
cipios de consulta y consentimiento no confieren a los pueblos indígenas un derecho a imponer unilateralmente su voluntad a los Estados que actúan legítimamente y de buena fe en bien del interés del público. Los principios de consulta y consentimiento están más bien encaminados a evitar que se imponga la voluntad de una parte sobre la otra y a que, en lugar de ello, se procure llegar a un entendimiento mutuo y adoptar decisiones por consenso".51

\section{V.4 La Evaluación de Impacto Ambiental}

Como parte del derecho de acceso a la información más general, el derecho a que se realice una Evaluación del Impacto Ambiental (EIA) para cualquier acción que tenga el potencial de afectar adversamente el medio ambiente y los recursos naturales ha sido reconocido como un componente crucial del debido proceso ambiental. El concepto de la EIA fue adoptado por una infinidad de documentos e instrumentos internacionales. ${ }^{52}$

51 ONU - Consejo de Derechos Humanos - Informe del Relator Especial sobre la situación de los derechos humanos y las libertades fundamentales de los indígenas, James Anaya. Doc. ONU A/HRC/12/34, 15 de julio de 2009, párrs. 48-49.

52 En 1987, las Naciones Unidas presentan un documento titulado "Objetivos y Principios de la Evaluación de Impacto Ambiental. En 1989 el Banco Mundial publicó sus Directrices para las Evaluaciones Ambientales y desde entonces las utilizó para evaluar los impactos de los proyectos que financia. En 1991, la Comisión de las Naciones Unidas para la Economía en Europa desarrolló las directrices entonces adoptadas por el Programa de las Naciones Unidas para el Medio Ambiente y adoptó el Convenio sobre Evaluaciones de Impacto Ambientales Transfronterizas, lo que es hoy el tratado internacional más completo sobre EIAs. La Declaración de Río establece a la EIA como uno de los principios del medio ambiente y desarrollo (Principio 17). El Convenio sobre diversidad biológica también prevé, en su artículo 14, la necesidad de EIAs para proyectos que puedan afectar la biodiversidad. 
En los Estados Unidos, en donde se desarrolló la EIA por primera vez como un principio legal,,$^{53}$ ese instrumento es considerado esencial para la evaluación de la viabilidad de los proyectos propuestos. En aquel país, el poder judicial generalmente ordena la suspensión de los proyectos de desarrollo, pequeños o grandes, aunque estratégicos, en el caso que los impactos ambientales no hayan sido adecuadamente evaluados.

En este momento en América Latina se ha producido un incremento de grandes proyectos extractivos, de generación de energía y de infraestructura a gran escala. Estos proyectos son impulsados por el aumento constante de la demanda de recursos naturales, minerales y energía, que incluyen la explotación forestal, la búsqueda de más recursos energéticos y la construcción de hidroeléctricas y carreteras. Además de esto se expanden los cultivos de plantaciones de semillas genéticamente alteradas. Estos proyectos pueden generar cambios masivos en la vida de las personas e impactan la naturaleza y el ambiente en la zona del proyecto y los alrededores con efectos impredecibles.

La fuente de la obligatoriedad por parte de los Estados para la realización de estudios sobre la incidencia

53 La primera norma norteamericana relacionada con las evaluaciones de impacto ambiental fue adoptada en 1969 cuando el público empezaba a reaccionar en contra de la degradación ambiental causada por los procesos de desarrollo. Desde entonces más de 100 países han adoptado legislación o políticas que incluyen alguna forma de EIA. Fuente PNUMA, Training Manual on International Environmental Law. 
social, espiritual, cultural y ambiental de las medidas, programas o proyectos, con participación de los pueblos se encuentra en el artículo 73 del Convenio 169 de la OIT, así mismo la Corte IDH lo establece claramente en la sentencia del caso Saramaka vs. Surinam, párrafo 130.

Algunos de estos proyectos si se desarrollaran de manera sostenible, podrían generar beneficios para los habitantes locales pero la manera de alcanzar esta meta es garantizando y fortaleciendo la participación de las comunidades, para que con la información adecuada y dispuesta de manera que sea culturalmente pertinente, $\mathrm{pu}^{-}$ edan opinar y sugerir las modificaciones que disminuyan las posibilidades de daño e incrementen los beneficios.

Sin embargo, la mayoría de las veces estos proyectos acarrean problemas e impactos negativos duraderos, que además de lesionar la naturaleza afectan los derechos de las personas que viven en el área de afectación. Una manera de detectar los probables efectos es escuchando a las personas antes de contratar los estudios de impacto ambiental, cultural o social. Nadie sabe mejor que las mismas comunidades cómo una obra o iniciativa los puede afectar y cómo proteger lo que es vital para su bienestar.

El objetivo principal de las Evaluaciones de Impacto Ambiental es que una obra o proyecto justificables desde el punto de vista económico, o de los intereses inmediatos de su proponente, considere los efectos, que en algunos casos podrían resultar nefastos o catastróficos 
para el medio ambiente. ${ }^{54}$ Además de eso, es un objetivo de la EIA incidir en la decisión administrativa sobre la aprobación del proyecto. Es decir, la decisión de llevar a cabo el proyecto u obra, o de no hacerla definitivamente, solamente debería ser tomada después de realizados los estudios y análisis debidos.

Una EIA sirve principalmente para: a) permitir que las cuestiones ambientales y sociales sean incorporadas en los procesos de planeación y toma de decisiones; b) anticipar y minimizar los impactos ambientales y sociales de un proyecto; c) favorecer la participación del público, una vez que el estudio de EIA establezca categóricamente cual sería el área de afectación, y d) evaluar la factibilidad de proyectos alternativos.

Estos estudios no deberían ser contratados por las empresas mismas, sino por el Estado con el dinero y la participación de las empresas y las comunidades, de manera que se elimine el riesgo que las instituciones que hagan los estudios tiendan a satisfacer a quien paga, para no quedar por fuera del mercado de este tipo de estudios, como lo revelan las experiencias de Cerro de Oro en Oaxaca, Puerto Brisa en el Caribe colombiano y la presa en territorio de los Guarijíos, en Sonora, México, en donde estudios mal hechos fueron la razón principal para que las consultas comenzaran y terminaran mal. El

54 Benjamin Milaré, "Estudo Prévio de Impacto Ambiental: teoria, prática e legislação". São Paulo: Revista dos Tribunais, 1993, p. 12. 
Estado tiene la responsabilidad de corroborar y monitorear el profesionalismo y objetividad de estos estudios y que en los mismos se incorpore y resuelvan las dudas que los pueblos y comunidades manifiesten a lo largo del proceso de consulta.

\section{Modalidad en la implementación del derecho a la consulta previa en diferentes países de América Latina. Consecuencias de una regulación deficitaria}

Hasta la fecha no hay ningún país en América Latina donde la población indígena y tribal se encuentre satisfecha con la implementación de este derecho. Como ya lo hemos mencionado Colombia es donde más consultas se han llevado a cabo y es donde mayor adecuación institucional y desarrollos jurisprudenciales se han dado, lo cual no excluye que todavía haga falta un mejor desarrollo y adecuación. En otros países se han producido énfasis que remarcan modelos de consulta particular, no que sean los únicos ni los dominantes, pero para efectos de mostrar la manera como se aplica este derecho creemos importante aludir a las diferentes vías predominantes, a partir de la observación sobre estas prácticas, vemos cuando menos los siguientes modelos de consulta previa:

Guatemala: indígenas sin Estado ni empresarios. Ante la ausencia de voluntad política del Estado 
para reglamentar e implementar la obligatoriedad de la consulta previa, cerca de un millón de indígenas se han movilizado entre el 2005 y el 2015 para la defensa de sus territorios y recursos, por medio de la organización de consultas que ellos denominan de "buena fe", pero donde la ausencia de Estado y empresarios en esas consultas disminuye el impacto jurídico y político que estas movilizaciones podrían tener. La escuela de ejercicio de la ciudadanía que la consulta puede ser, donde los pueblos originarios se capacitan sobre sus derechos y aprenden a ejercerlos en la negociación y en su judicialización cuando se perciben fallos graves, no cumple cabalmente esta función en esta forma de consulta en Guatemala por la ausencia de la contraparte y del Estado.

Como lo anotó el Relator Especial de la ONU sobre derechos humanos de los pueblos indígenas en su visita of icial a Guatemala en junio del 2010, la ausencia de la reglamentación interna ha generado además de los pueblos indígenas, respuestas por parte de las propias empresas. "[...]. Aún reconociendo los esfuerzos llevados a cabo por éstas [las empresas] para paliar la ausencia de procedimientos formales, estos esfuerzos han sido a todas luces insuficientes. En este sentido, me gustaría puntualizar que, dentro de la diligencia debida que les corresponde en relación con el respeto de los derechos indígenas, las empresas no pueden ni deben llevar a cabo procesos de consulta que sustituyan las obligaciones que 
corresponden a las autoridades competentes en esta materia, sin la involucración activa de estas autoridades y sin su supervisión directa. Asimismo, debe tenerse en cuenta que la consulta implica siempre un diálogo activo que no se agota en un trámite inicial, sino que debe representar un diálogo continuo. Dicho diálogo debe enmarcarse no sólo en la buena voluntad, sino en el pleno respeto de los derechos que le corresponden a los pueblos indígenas en el contexto de proyectos que afecten sus territorios tradicionales". ${ }^{55}$ En este mismo orden de ideas, y como lo expresó la Corte de Constitucionalidad de Guatemala en el 2007, al ser interrogada sobre el impacto de estas consultas de buena voluntad, esta respondió que desde el punto de vista de su legitimidad social constituía una buena práctica, con importantes efectos en cuanto al ejercicio de participación comunitaria, los esfuerzos de las propias comunidades de adelantar consultas sin la presencia del Estado ni de las empresas, adolece de efectos nulos respecto al carácter vinculante para el Estado, en cuanto éste no la había convocado, ni había participado.

En relación con el argumento del gobierno de Guatemala en el sentido que la ausencia de una ley reglamen-

55 United Nations Human Rights. Office of the High Commissioner for Human Rights, Observaciones preliminares del Relator Especial de Naciones Unidas sobre la situación de los derechos humanos y las libertades fundamentales de los indígenas, S. James Anaya, sobre su visita a Guatemala (13 a 18 de junio de 2010). http://www.ohchr.org/en/NewsEvents/Pages/DisplayNews.aspx?NewsID=10173\& LangID=S\#sthash.1DG8EFJC.dpuf 
taria de la consulta la hace inaplicable, el relator especial responde: "Desde la perspectiva del derecho internacional de los derechos humanos, sin embargo, esta posición no es sostenible. Las disposiciones del Convenio 169 son directamente ejecutables y de obligado cumplimiento por todos los agentes públicos. Esta conclusión ha sido reforzada por la jurisprudencia de la Corte de Constitucionalidad, que ha afirmado expresamente que la consulta constituye un derecho fundamental, integrante del bloque de constitucionalidad, al mismo nivel que otros derechos reconocidos en la Constitución. El argumento de la falta de obligatoriedad de la consulta a los pueblos indígenas ha contribuido en gran medida a la situación de grave inseguridad jurídica que afecta actualmente a las actividades extractivas y de inversión en el país".56

Chile: empresarios e indígenas, sin Estado.

Durante los últimos 5 años empresas madereras han logrado cerca de 300 acuerdos con comunidades indígenas en el sur del país, a partir de procesos logrados en lo que ellos llaman procesos de consentimiento. Según voceros de una empresa que certifica la explotación maderera, se tomó la decisión de optar por hacer estos procesos sin la participación del Estado en la medida que éste está muy burocratizado y la legislación es deficiente para facilitar estos procesos. Las empresas, según estos voceros, son más eficaces toda vez que el debate se limita ${ }^{56}$ Ibídem. 
a lo que es "realista" dejando por fuera lo que sólo podría ser materia de la intervención del Estado, por ejemplo lo que tiene que ver con la titulación de la propiedad de la tierra, lo que es un reclamo histórico y permanente de los pueblos indígenas mapuches.

El Estado, en este contexto es visto como un "tercero" cuya participación como árbitro, debe ser aceptada con anticipación por las partes. Donde como se ve en lo trascrito, al no estar el Estado ejerciendo su papel de acuerdo a los estándares internacionales, se pierde la oportunidad que las instituciones y los funcionarios se transformen en la adaptación que tendría que ocurrir, si el Estado ejerciera su papel y tuviera la voluntad de honrar los convenios internacionales que ha suscrito. Los pueblos indígenas mapuches, niegan que esto que hacen las empresas constituyan consultas previas, argumentan que si algunas comunidades acceden a estas negociaciones con las empresas se debe a su precariedad económica, lo que es aprovechado por las empresas que con la complicidad del Estado permiten estos acuerdos privados, en cuanto alivia al Estado de tener que reglamentar las consultas con los problemas que esto traería respecto al carácter vinculante de los estándares que existen.

En Colombia por ejemplo, la participación del Estado en todas las consultas ha dado lugar a que las instituciones hayan tenido que crear grupos de funcionarios capacitados en consulta previa y en los espacios que las 
consultas generan se pone sobre la mesa todos los ajustes y rectificaciones que el Estado debe hacer. La Corte Constitucional y el poder judicial en general, por medio de sentencias ordena al Estado a indemnizar a los indígenas cuando a ello diera lugar, titular territorios indígenas, sanearlos, regular las obligaciones que las empresas tienen de acuerdo con el modelo que se ha creado por el monitoreo que los jueces hacen de estos procesos. A pesar de estos avances tampoco es que todo funcione bien, como se describe a continuación.

Colombia: Donde más procesos de consulta se han dado con la participación del Estado, empresarios e indígenas y donde el Estado mejor se ha adaptado al ejercicio de este derecho fundamental e instrumental para el ejercicio de otros derechos, pero donde todavía hay mucho en que avanzar. Persisten graves problemas de corrupción de líderes e intermediarios, que por un precio se comprometen a agilizar las consultas, en particular en comunidades afrodescendientes, muchas de estas prácticas son promovidas por el mismo Estado, en su afán por conseguir la "eficiencia". También persiste una seria asimetría en relación con el control financiero que las empresas tienen, en temas fundamentales como son los estudios de impacto ambiental y el pago de trasporte y alojamiento de quienes participan en las consultas, incluyendo los mismos funcionarios del Estado, todo lo cual es controlado por las empresas. 
La Corte Constitucional ha abandonado posiciones garantistas que apoyaban el consentimiento cuando las condiciones así lo ameritaban, bajo el argumento que el Convenio 169, que es la base legal de este derecho, sólo trata de la consulta y no del consentimiento, que al ser planteado por la Declaración sobre los Derechos de los Pueblos Indígenas de las Naciones Unidas, no tiene el carácter vinculante que sí tiene el Convenio.

México: sin Estado, indígenas ni empresarios.

Sin duda donde la brecha de implementación (la distancia que existe entre las leyes en el papel y las leyes en el terreno) ha sido más notoria. De hecho el mapa de conflictividad que se observa en el país en la actualidad, coincide con lugares afectados por proyectos extractivos o megaproyectos donde no se ha dado ningún tipo de consulta, tales son los casos de la Parota en el Estado de Guerrero, el parque eólico en el Istmo de Tehuantepec, la hidroeléctrica en territorio de los yaquis, las minas de Cananea en Sonora, y Zacualpan en Colima que afecta a los nahuas, sólo por mencionar algunos de los conflictos que más cobertura mediática han tenido.

Las repercusiones no sólo generan problemas de gobernanza y gobernabilidad sino que también afectan la confianza inversionista, como en el caso de Cerro de Oro (Oaxaca), donde los empresarios perdieron una suma de varios millones de dólares una vez que las comunidades se enteraron del derecho que tenían de ser 
previamente consultados y aprovecharon la coyuntura política del cambio de régimen en el Estado, para rechazar tajantemente la construcción de una hidroeléctrica que ya tenía más de dos años de haberse iniciado sin consulta previa. Como lo hemos mencionado la obligación de exigir y monitorear la consulta es del Estado, por lo que situaciones como la que se presentó en Cerro de Oro, donde empresarios privados perdieron una considerable inversión y los conflictos sociales que se han generado a lo largo del país donde se han adelantado proyectos extractivos y de generación de energía, son responsabilidad de la omisión del Estado.

Desde hace varios años la institución responsable del tema indígena, la Comisión Nacional para el Desarrollo de los Pueblos Indígenas (CDI), ha venido invirtiendo dinero y tiempo en consultas sobre temas que no afectan lo estructural referido a tierras y recursos naturales. En este orden la CDI ha realizado consultas sobre alcoholismo, sobre migración, sobre VIH y la que en opinión de quien era el Director de Consulta y Participación Indígena de la Unidad de Planeación y Participación de la CDI ha sido la mejor consulta realizada a la fecha que fue la consulta con autoridades wixárikas sobre lugares sagrados, llevada a cabo entre los años 2006 y 2007. Por la importancia cultural y simbólica de la tradición wixárika, además de esta consulta que concluyó en el pacto de Hauxa Manaka en abril del 2008, con la presen- 
cia del presidente de la república y cinco gobernadores de los Estados donde se ubican los lugares sagrados. En los años 1994, 2000, 2008 y 2010 se han emitido decretos estatales y acuerdos con los gobiernos estatales y federal, los que entran al detalle sobre las responsabilidades del Estado en cuanto a la protección de estos derechos especiales. Es así como el sendero con sus lugares sagrados y la peregrinación, así como el entorno natural, el paisaje, todo el camino para llegar a Wirikuta, el hicuri (peyote), los depósitos de agua que son sagrados para los wixárikas, todo esto se encuentra protegido por legislación especial. Pero a pesar de toda esta promulgación de normas legales y la consulta llevada a cabo con mucha cobertura mediática, el 10 de noviembre del 2010, se cerró un acuerdo de explotación minera que afecta Wirikuta, el sendero sagrado y el $68 \%$ del territorio protegido, entre el gobierno de México con First Majestic, una multinacional canadiense sin que se diera la consulta previa con las comunidades afectadas. Las comunidades afectadas presentaron una demanda de amparo ante el Juez de Distrito en materia Administrativa en la Ciudad de México, la cual fue fallada a favor de las comunidades suspendiéndose la concesión otorgada por el gobierno federal a la minera canadiense.

Perú: Estado y empresas sin indígenas.

En Perú el debate se retrotrae a la eliminación del 
carácter indígena de los pueblos originarios de los Andes, campesinados por decreto, donde el carácter indígena lo atribuye el Estado solamente a los pueblos amazónicos. Sobre la base de este argumento que riñe con preceptos básicos de la antropología, se pretende excluir a pueblos milenarios de la protección de normas de origen internacional. El argumento del gobierno sobre que estos pueblos dejaron de ser indígenas por la intervención del Estado, ignora que estos pueblos poseen territorios comunales, autoridades e idiomas propios, sistemas de justicia, espiritualidad, trajes, celebraciones, usos y costumbres.

El origen de esta peculiar situación se remonta a 1969 cuando el gobierno militar decidió vía decreto abolir la comunidad indígena y darle el nombre de comunidad campesina, con lo que dejaba entrever era una apuesta desarrollista que pretendía "integrar" a los antiguos indios, renombrados como campesinos, que tenían que dejar su condición étnica y asumir su condición de productores, aceptando las reglas del mercado y de los nuevos tiempos que se iniciaban.

Algo parecido ocurre en Bolivia donde bajo el argumento del "interés nacional" se limita la participación indígena en procesos de consulta. Las decisiones de fondo se dan a puerta cerrada donde el Estado asume la representatividad del interés nacional y acuerda con las empresas los proyectos. 
Así quedó decidido en la Ley que reglamentó el precepto constitucional de la Consulta donde se excluye el elemento del consentimiento y se limitan los alcances del proceso de consulta, al eliminar el carácter vinculante de las decisiones a que se lleguen durante las negociaciones, dice el texto de la ley: "sin embargo en cuanto a las conclusiones, acuerdos y decisiones tomadas estas no tienen carácter vinculante, pero deberán ser considerados por las autoridades y representantes en los niveles de decisión que corresponda". ${ }^{57}$

En Brasil se da una situación similar, pues en varias oportunidades agentes gubernamentales de las más altas esferas, han sido explícitos al definir la posición oficial del Estado brasileño respecto a este derecho, donde se afirma que la última palabra la tiene el Estado bajo el argumento del interés público estratégico, lo que se traduce en que aun cuando los indígenas estén en total desacuerdo con la implementación de un proyecto específico si éste es definido por el Estado como imprescindible, será hecho.

La posición de estos tres Estados convierte en la práctica la consulta en un formalismo administrativo, lo que va en contravía con lo que ha dispuesto la Corte IDH, que ha sido enfática respecto a que las consultas deben realizarse de buena fe, a través de procedimientos cul-

57 Artículo 39 de la Ley 026 de Régimen Electoral promulgada el 30 de junio de 2010. 
turalmente adecuados y que deben tener como fin llegar a un acuerdo (párrafo 177 de la sentencia Sarayaku vs. Ecuador). Así mismo que la consulta no debe agotarse en un mero trámite formal, sino que esta debe concebirse como un verdadero instrumento de participación, que "debe responder al objetivo último de establecer un diálogo entre las partes basado en principios de confianza y respeto mutuos y con miras a alcanzar un consenso entre las mismas" (párrafo 186 de la sentencia).

\section{Titularidad de la tierra e impactos y efectos de iniciativas y proyectos a las comunidades}

La consulta y el consentimiento libre, previoe informado es un derecho colectivo importante que puede contribuir a que los proyectos sean más sostenibles y que su impacto sea compensado o aminorado. Los pueblos indígenas pueden reivindicar su ejercicio cuando un proyecto impacta en sus vidas, su subsistencia o sus tierras y territorios. Según sentencias de la Corte IDH este derecho es reivindicable para las comunidades indígenas no siendo excluyente si las tierras que estos poseen y ocupan se encuentran tituladas o no.

El Relator Especial para los Pueblos Indígenas de la ONU, observa con preocupación que algunos Estados, de hecho o de manera deliberada, han adoptado la posición que las consultas directas con los pueblos indígenas en 
relación con proyectos de cualquier naturaleza que afecta o amenaza tierras y territorios indígenas, sólo se requieren cuando las tierras en que se realizan las actividades en cuestión han sido reconocidas como tierras indígenas por el derecho interno. Esta posición carece de fundamento pues, de la misma manera como ocurre con el derecho a la libre determinación y con los principios democráticos y debido a las condiciones generalmente vulnerables de los pueblos indígenas, el deber de celebrar consultas con ellos se plantea siempre que estén en juego sus intereses particulares, incluso si dichos intereses no corresponden a derechos que se encuentren titulados o reconocidos.

El comité tripartito del Consejo de Administración de la OIT af irmó explícitamente que la consulta procede respecto de los recursos de propiedad del Estado que se encuentren en las tierras que los pueblos interesados ocupan o utilizan de alguna manera, tengan o no título de propiedad sobre los mismos. El Informe de la Comisión de Expertos en Revisión de Convenios y Recomendaciones de la Organización Internacional del Trabajo en el año 2007 señala:

"La Comisión recuerda que el Convenio protege no sólo a las tierras sobre las cuales los pueblos interesados ya tienen título de propiedad sino también a las tierras que tradicionalmente ocupan, y que, en virtud del Convenio, los Gobiernos deberán tomar las medidas que sean necesarias para determinar las tierras que los 
pueblos interesados ocupan tradicionalmente y garantizar la protección efectiva de sus derechos de propiedad y posesión (artículo 14, párrafo 2). En este sentido, las disposiciones que tratan de la cuestión de las tierras en el Convenio, y más concretamente los artículos 13 y 14 , deben ser interpretadas en el contexto de la política general expresada en el artículo 2, párrafo 1, según el cual los gobiernos deberán asumir la responsabilidad de desarrollar, con la participación de los pueblos interesados, una acción coordinada y sistemática con miras a proteger los derechos de esos pueblos y a garantizar el respeto de su integridad. Dichas disposiciones además deben articularse en la práctica con la implementación de los procesos de consulta con los pueblos interesados del artículo 6. Por lo tanto, la Comisión espera que el Gobierno dé plena aplicación a los artículos mencionados en el curso de la delimitación de las tierras ocupadas tradicionalmente por las comunidades referidas, y solicita la mantenga informada al respecto, en particular sobre la manera en que las comunidades participan en dicho proceso, así como sobre los resultados de las medidas adoptadas para recuperar las tierras indebidamente ocupadas por personas que no pertenezcan a las comunidades". ${ }^{58}$

Efectos positivos o beneficios de proyectos: Generación de fuentes de trabajo para los miembros de la co-

58 Informe Comisión de Expertos en aplicación de Convenios y Recomendaciones III (Parte 1 A), Convenio núm. 169, Colombia, párrafo 5. 
munidad, capacitación, desarrollo de habilidades. Mejor provisión de agua y saneamiento. Mejoras en la producción de alimentos. Beneficios financieros. Mejoramiento en la inf raestructura y construcción de carreteras, caminos, escuelas, clínicas y viviendas.

Efectos negativos y riesgos: Disparidad entre las promesas que se hace a las comunidades y los efectos que suceden en realidad. Los trabajos of recidos a las comunidades generalmente suelen ser temporales. Pueden contaminar el aire y el agua que nutre su comunidad. Con las obras se incrementa la presión para abandonar sus propias tierras. Se niega el acceso a las tierras empleadas para producir alimentos y para llevar a cabo rituales y tradiciones culturales. Puede darse un impacto a la naturaleza que afecte la reproducción de especies acuáticas o terrestres y flora en la región. Si la obra trae consigo el incremento de trabajadores foráneos se puede generar aumento de la violencia y el estrés social como vandalismo, alcoholismo y prostitución, con riesgos para la salud de las comunidades derivados del desplazamiento de los trabajadores hacia el lugar del proyecto. Así mismo se pueden dar repercusiones negativas después que la empresa haya abandonado el área, dejando una huella de material tóxico, piezas de material que no es biodegradable, etc. 


\section{Alcances de la Consulta y términos legales}

La Comisión de Expertos en Aplicación de Convenios y Recomendaciones de la OIT, en su Observación General de 2011, sobre la obligación de consultar bajo el Convenio 169 de 1989, manifestó que:

1) las consultas deben ser formales, plenas y llevarse a cabo de buena fe; debe producirse un verdadero diálogo entre los gobiernos y los pueblos indígenas y tribales caracterizado por la comunicación y el entendimiento, el respeto mutuo, la buena fe y el deseo sincero de alcanzar un acuerdo;

2) tienen que establecerse mecanismos apropiados a escala nacional y ello debe realizarse de una forma adaptada a las circunstancias;

3) tienen que llevarse a cabo consultas a través de instituciones representativas de los pueblos indígenas y tribales en relación con las medidas legislativas y administrativas;

4) deben llevarse a cabo consultas con el objetivo de llegar a un acuerdo o lograr el consentimiento sobre las medidas propuestas.

En lo que respecta a las demás comunidades afectadas por proyectos, su participación plena y efectiva en las negociaciones sobre la planificación e implementación de estos proyectos también debe ser asegurada. Incluso en países en que las leyes nacionales sólo con- 
templan una protección débil del derecho a la consulta. Es importante recordar que el derecho de los pueblos afectados por proyectos a ser consultados y a participar en el proceso de toma de decisiones, se expande más allá de los derechos específicos para pueblos indígenas y tribales, se encuentra en tratados internacionales como los ya mencionados en el presente manual. Asimismo debemos recordar que instituciones financiadoras internacionales como el Banco Mundial y el BID, tienen disposiciones que obligan a la participación y consulta de todas las comunidades afectadas por proyectos financiados total o parcialmente por éstas.

La consulta y el consentimiento libre, previo e informado habla de un derecho específico de las comunidades indígenas que los demás deben respetar. Es un derecho colectivo. Esto significa que la comunidad, como conjunto, tiene el derecho de ser informada y consultada, así como dar o negar su consentimiento libre, previo e informado.

Cada palabra de la definición legal tiene un significado importante desde el punto de vista de derechos para la comunidad. Veamos lo que cada una significa:

Consulta: preguntar, dialogar, escuchar, evaluar, acordar, implementar.

Consentimiento: autorizar, asentimiento, permiso, dar el visto bueno para algo o negarlo, aprobar o desaprobar.

Libre: significa sin fuerza, intimidación, manipulación, chantaje, coerción o presión por parte de cual- 
quier funcionario del gobierno o empresa.

Previo: quiere decir antes de dar u otorgar una autorización, concesión, permiso o asignación de tierras para un uso específico y a la aprobación de proyectos específicos por parte del gobierno. Se debe dar suficiente tiempo a las comunidades para que de acuerdo con sus usos y costumbres, tradición, o formas propias, puedan considerar toda la información, procurar asesorías y tomar una decisión.

Informado: Este punto es fundamental y constituye generalmente un nudo gordiano del proceso de consulta, refiere a que se les debe entregar a la comunidad toda la información relevante para que puedan formarse una idea y tomar la decisión de expresar su acuerdo o desacuerdo. Los Estudios de Impacto Ambiental (social, cultural, espiritual) de preferencia deben ser ordenados por una institución oficial independiente de quienes tienen interés en el desarrollo del proyecto.

Esta información debe tener acceso no sólo a lo provisto por el desarrollador del proyecto o el gobierno. También deben tener acceso a expertos independientes en materia legal y técnica, que les ayuden a comprender la información que es relevante conocer antes de tomar una decisión.

El consentimiento exige que las personas involucradas en el proyecto permitan a las comunidades indígenas decir sí o no al proyecto y en cada fase del mismo, 
según el proceso de decisión que éstas hayan elegido. El derecho de dar o negar el consentimiento es la diferencia más importante entre los derechos de los pueblos indígenas y los de otras comunidades que no tienen esta condición pero que son afectados por proyectos.

Para los pueblos no indígenas, el derecho a ser consultados y negociar en los procesos de toma de decisiones que les afecten debe guiarse por estos principios, de manera que la consulta y la negociación deben realizarse únicamente sin que la comunidad sea obligada o presionada a participar y en forma previa a la toma de decisiones, y sólo debe buscarse su consentimiento cuando esté plenamente informada de las cuestiones que se discuten y negocian.

\section{Características e importancia de los pasos que deben orientar la consulta y el consentimiento}

Algunas comunidades eligen representantes comunitarios para que negocien con el desarrollador del proyecto en nombre de la comunidad entera. Frente a este punto y tomando en cuenta lo que nos enseña la experiencia, lo que recomendamos es que los representantes sean voceros pero no quienes deciden asuntos de fondo, esto debe estar reservado para la Asamblea Comunitaria, los representantes llevan a la Asamblea los temas y las propuestas y que sea esta la que tome las decisiones definitivas. Cada comunidad tiene el derecho de determinar el 
procedimiento que consideren más conveniente, tomando en cuenta la necesidad de protegerse de que sus representantes puedan ser objeto de presiones o chantajes que vicien el proceso de negociación.

Paso 1:

Establecer quién o quiénes están desarrollando el proyecto propuesto. En primer lugar, es necesario saber quién lo está planificando y en qué forma puede afectar a su comunidad. Averiguar de qué trata, para a partir de esta información establecer cuáles son las instituciones del Estado que tienen la obligación de supervisar, asesorar, y responder las dudas o cuestionamientos que pue-dan surgir de parte de las comunidades, dependiendo la materia que sea. Las instituciones tienen la obligación de proveer o recabar la información que las comunidades soliciten.

En relación con los objetivos específicos del proceso de consulta previa, la Corte Constitucional de Colombia destaca tres:

a) Que la comunidad tenga un conocimiento pleno sobre los proyectos destinados a explorar o explotar los recursos naturales en los territorios que ocupan o les pertenecen, los mecanismos, procedimientos y actividades requeridos para ponerlos en ejecución.

b) Que igualmente la comunidad sea enterada e ilustrada sobre la manera como la ejecución de los referidos proyectos puede conllevar una afectación o menoscabo 
a los elementos que constituyen la base de su cohesión social, cultural, económica y política y, por ende, el sustrato para su subsistencia como grupo humano con características singulares.

c) Que se le dé la oportunidad para que libremente y sin interferencias extrañas pueda, mediante la convocación de sus integrantes o representantes, valorar conscientemente las ventajas y desventajas del proyecto sobre la comunidad y sus miembros, ser oída en relación con las inquietudes y pretensiones que presente, en lo que concierna a la defensa de sus intereses y pronunciarse sobre la viabilidad del mismo. Se busca con lo anterior, que la comunidad tenga una participación activa y efectiva en la toma de la decisión que deba adoptar la autoridad, la cual en la medida de lo posible debe ser acordada o concertada.

Los planificadores y desarrolladores del proyecto pueden incluir las siguientes entidades: el gobierno; una empresa privada (como una empresa minera o constructora); el gobierno o una institución de otro país; una autoridad local (como una agencia de protección medioambiental o el departamento público del ambiente y/o de recursos naturales); un banco o una institución financiera nacional o internacional (como el Banco Mundial o el Banco Interamericano de Desarrollo o una agencia financiadora o de desarrollo de otro país). 
Paso 2:

Es importante que toda la comunidad, de la manera que sea cultural o lingüísticamente pertinente, sea informada sobre el proyecto, sus posibles impactos y lo que el desarrollador del proyecto hará para prevenirlos o reducirlos. Es esencial solicitar copias de las evaluaciones de impacto medioambiental y social de manera que sea comprensible en el idioma y cultura propia. Para ello, se recomienda nombrar unas dos o más personas de total confianza de la comunidad, que sean buenos hablantes del idioma local y el idioma oficial del país (castellano o portugués), para que reciba capacitación de alguna agencia del Estado o ONG para que puedan traducir e interpretar adecuadamente los términos técnicos de la información relevante que se genere.

Ello, permite asegurar que todos los miembros de la comunidad sean debidamente informados y comprendan los posibles impactos del proyecto. También ayuda a evitar que el proceso de negociación sea capturado por algunos pocos miembros, quienes podrían ser tentados a estar más interesados en su beneficio personal que en el de la comunidad.

Los representantes que la comunidad designe deben ser el fruto de decisiones soberanas tomadas a nivel de la Asamblea comunitaria sin la interferencia del gobierno y mucho menos de la empresa interesada en el desarrollo del proyecto. Sobre el particular en la senten- 
cia del pueblo de Saramaka vs. el Estado de Surinam, ${ }^{59}$ la Corte Interamericana reconoció que deliberadamente omitió señalar quiénes deberían ser específicamente los consultados, puesto que esa decisión recaía en el Pueblo Saramaka y no en el Estado. Reiteró que la consulta se debe realizar de conf ormidad con las costumbres y tradiciones del pueblo en cuestión, siendo el pueblo el que decida sobre quién o quiénes lo representarán en cada proceso de consulta.

Un mecanismo recomendable para evitar la $\mathrm{co}^{-}$ rrupción de quienes hablan a nombre de la comunidad es que los representantes no tengan carácter decisorio, éste debe tenerlo la Asamblea de la comunidad, los representantes deben ser interlocutores con los desarrolladores del proyecto y el Estado, pero las decisiones las debe tomar la comunidad una vez los representantes comunitarios presenten a la Asamblea informes sobre el Estado de la negociación y las propuestas que hay en la misma.

Un modo para obtener información es por medio de preguntas estructurales al desarrollador del proyecto. Las respuestas se podrán grabar y llevar esta información a su comunidad para que se discuta conjuntamente.

59 Corte IDH. Caso del Pueblo Saramaka vs. Surinam. Interpretación de la Sentencia de Excepciones Preliminares, Fondo, Reparaciones y Costas. Sentencia de 12 de agosto de 2008 Serie C No. 185, párr. 18. 
A continuación veremos, a manera de ejemplo para otros países, la ruta que se ha implementado en $\mathrm{Co}^{-}$ lombia, el país de América Latina donde más consultas se han llevado a cabo.

El primer paso es la certificación sobre existencia de pueblos o comunidades étnicas que puedan ser afectadas por tal proyecto o iniciativa. El Estado a través de sus instituciones correspondientes, que tendrían que ser de dos órdenes al menos: la que implementa este derecho, por ser la especializada en el tema objeto de la consulta, si es minería, el ministerio de minas, si es hidroeléctrica la que se encargue del tema de aguas y medio ambiente, etc.

Y otra que es la institución garantista, es decir la responsable de garantizar que las comunidades étnicas estén bien representadas, que a lo largo del proceso de consulta se respete la pertinencia cultural y lingüística, etc. Esta segunda que se supone es la especialista, al interior del Estado, en el tema de derechos de los pueblos y comunidades étnicas, tendría que certificar, como primer paso, si en la zona de influencia donde se piensa instalar el proyecto objeto de la consulta, hay presencia de pueblos o comunidades étnicas. Esta certificación no se limita a considerar el espacio de presencia física sino que debe incluir también aquel en el que se desarrollan las prácticas tradicionales de dichos pueblos, tales como: caza, pesca, recolección de frutos y rituales propios de su 
concepción religiosa o espiritual, entre otras. ${ }^{60}$

Es importante aclarar que sólo por medio de estudios de impacto ambiental, hechos con la rigurosa supervisión del Estado y con la participación de las comunidades certificadas, se podrá establecer cuál sería realmente el área de afectación y de esta manera cuáles podrían ser las comunidades o pueblos afectados, a los que se les debe igualmente garantizar su participación en el proceso de consulta.

Segundo paso, la pre-consulta. Durante esta fase se realiza la labor de coordinación institucional y comunitaria, se adoptan junto con las comunidades y los demás actores del proceso las reglas bajo las cuales se desarrollará el proyecto o la ruta metodológica. Así, se planean conjuntamente los tiempos y los planes de trabajo, se informa a la comunidad acerca del proyecto, sus impactos -positivos y negativos- se determina quién, cuándo y cómo haría los estudios correspondientes de impacto ambiental, social y cultural y se procuran los espacios de reflexión interna de la comunidad.

Tercer paso, apertura o instalación de la consulta. Tanto la Dirección de Consulta Previa que está instalada en el Ministerio del Interior, como la empresa interesada presentan información introductoria acerca de:

- El marco legal del proceso, de los sujetos que van a intervenir por parte de la comunidad y del solicitante,

${ }^{60}$ Corte Constitucional de Colombia, Sentencia T-693 de 2011. 
sus facultades, así como los garantes y acompañantes del proceso (autoridades nacionales, locales y organizaciones étnicas). El tipo de proyecto que se desarrollará en la zona. Sus apreciaciones y discusión de los temas planteados. Una vez se surte la presentación, se efectúa la instalación formal del proceso de consulta previa.

- Talleres de identificación de impactos y defi-nición de medidas de manejo. Se efectúan reuniones de trabajo, en las que se realizan, entre otras, las siguientes actividades:

- Socialización detallada y exhaustiva del proyecto, obra o actividad a ejecutar, sus ventajas y desventajas.

- Conformación de los grupos de trabajo.

- Elaboración y evaluación de los estudios de identificación de impactos ambientales y sociales.

Cuarto paso, pre-acuerdos. Durante esta fase se identifican los acuerdos preliminares sobre el proceso y se acuerdan las medidas de mitigación.

Quinto paso, protocolización del acuerdo. Se formaliza el proceso mediante un documento de conclusiones o acta de protocolización de la consulta previa, en donde las comunidades y las autoridades plasman $u$ of $i^{-}$ cializan los acuerdos. En esta fase, al igual que en las otras, el Estado juega un papel importante, además de lo ya advertido en el sentido que es con la intervención del Estado que se puede equilibrar la grave asimetría que existe entre comunidades étnicas con empresas, algunas veces grandes corporaciones con todo tipo de apoyos jurídicos 
y gran poder económico y político, la participación del Estado brinda seguridad a las partes, pues es común en el mundo empresarial que una empresa venda a otra un proyecto que ya está avanzado, es el Estado quien puede blindar los acuerdos y las consecuencias que emerjan de ellos, de manera que si se produce un cambio entre los actores, los acuerdos se honren de cualquier forma.

Sexto paso, sistematización y seguimiento al cumplimiento de los acuerdos. Se debe hacer una revisión periódica y un seguimiento constante de los acuerdos logrados entre las partes (Estado, comunidad, empresa o entidad) en la fase de concertación y consignados en el acta de protocolización, que idealmente tendría que ser protocolizada o autenticada por el Estado. En esta fase es fundamental involucrar todos los posibles escenarios que pueden ocurrir una vez se haya completado el proceso de consulta, por ejemplo si quedarán desechos o materiales en los territorios de la comunidad, iqué se hace con ellos?, ¿quién debería responsabilizarse por remover lo que sea posible para que en lo posible las tierras puedan recuperar su vocación anterior al proyecto?

Séptimo paso, cierre del proceso de consulta. Se da una vez que se cumplen con la totalidad de los acuerdos fijados ${ }^{61}$ y se haya acordado un mecanismo que garan-

61 Ministerio del Interior, La Consulta Previa en Colombia. 14 de febrero de 2013. Disponible en: http://www.minminas.gov.co/minminas/downloads/archivosEventos/9985.pdf Ministerio del Interior, La Consulta Previa a gruposétnicos en Colombia. Compendio de legislación, jurisprudencia y documentos de estudio, 2009, p. 639. 
tice que las consecuencias, aun las no totalmente previstas, cuenten con un responsable y garantía de cumplimiento.

El Tribunal Constitucional de Perú, en la sentencia 0022-2009-PI/TC, identificó las reglas que deben ser observadas para llevar a cabo procesos de consulta previa con las comunidades que puedan resultar afectadas con medidas legislativas o administrativas.

El tribunal señala las siguientes pautas para que se pueda configurar correctamente el proceso de consulta:

"1) El inicio de todo el proceso será la determinación de la medida legislativa o administrativa que puede ser susceptible de afectar directamente a un pueblo indígena. Esta tarea debe ser realizada por la entidad que está desarrollando tal medida.

2) Se deben determinar todos los pueblos indígenas posibles de ser afectados, a fin de notificarles de la medida y de la posible afectación.

3) Una vez notificados los sujetos que intervendrán, se debe brindar un plazo razonable para que los pueblos indígenas puedan formarse una opinión respecto a la medida. Luego tendrá que pasarse a la negociación propiamente dicha.

4) Si es que el pueblo indígena se encuentra de acuerdo con la medida entonces, concluye la etapa de negociación.

5) De lo contrario, si es que el pueblo indígena rechaza 
la medida propuesta precluye una primera etapa de negociación. Con ello se pretende hacer visible los puntos sobre los cuales existe disconformidad. Este colegiado estima pertinente que en este punto de la etapa la medida no podrá ser implementada. Para poder lograr ello, se tendrá que iniciar una segunda etapa de negociación dentro de un plazo razonable. Si es que a pesar de los esfuerzos realizados por las partes, no se alcanza consenso alguno, sólo entonces el Estado podrá implementar la medida, atendiendo en lo posible a las peticiones del pueblo indígena". ${ }^{62}$

\section{X.Preguntas frecuentes relativas a la información previa}

A continuación a manera de ejemplo algunas preguntas, que dan una idea del tipo de información previa que es útil recabar:

A) Comprender el proyecto

1. ¿Cuál es o son los propósitos del proyecto? ¿En qué consiste? ¿Para qué se hará?

2. ¿Cuál es el monto aproximado de inversión? ¿Qué tan grande es? ¿Cuál es el área de afectación?

3. ¿Cuándo comienza a ser construido? ¿Durante cuánto tiempo? ¿Cuánto tiempo va a operar?

62 Tribunal Constitucional de Perú, sentencia 0022-2009-PI/TC. Citado en El derecho a la consulta previa, libre e informada de los pueblos indígenas. La situación de Bolivia, Colombia, Ecuador y Perú. Documento de la Fundación Debido Proceso Legal, para OXFAM América, 2011. 
4. ¿Quiénes son los desarrolladores del proyecto? ¿Cuál es la trayectoria y el desempeño de la empresa en el pasado? ¿Cuál es su reputación?

5. ¿Cuál es la actividad principal y la nacionalidad de cada uno de los desarrolladores del proyecto?

6. ¿Quién estará involucrado en el proyecto además de la empresa o el gobierno (por ejemplo: proveedores, contratistas)?

7. ¿Qué clase de apoyo brinda el gobierno (por ejemplo: exención o reducción de impuestos para los desarrolladores del proyecto, menores costos para el acceso y uso de tierras)? 8. ¿Cuál es la opinión de los órganos locales de gobierno en relación con el proyecto?

9. ¿Quién financia la obra? ¿Quién provee los préstamos de inversión (por ejemplo: un banco comercial, el Banco Mundial, un fondo de inversión nacional o extranjero?

B) Impacto del proyecto

10. ¿Qué se va a construir para el proyecto (por ejemplo: vías, rutas, represas, grandes polos energéticos)?

11. ¿Hay algún mapa que marque las tierras afectadas? ¿Alguno de los efectos sobre las tierras y otros recursos podría ser permanente?

12. ¿El desarrollador del proyecto, prevé realizar evaluaciones de impacto ambiental, social, cultural, en materia de género y de derechos humanos?

13. ¿Cuáles son los riesgos potenciales del proyecto (por 
ejemplo: contaminación o alguna forma de deterioro del medio ambiente, depósito de material tóxico o incursión o afectación en un sitio o área sagrada)?

14. ¿Hay algún informe independiente que detalle estos riesgos y las medidas que se tomarán para mitigar los daños y está éste disponible para la comunidad?

15. ¿Qué beneficios habrá para las comunidades locales (por ejemplo: escuelas, hospitales, vías y otros programas de desarrollo social)?

16. ¿Contribuirá o no el proyecto a afianzar la tenencia de tierras por parte de la comunidad? ¿Si los desarrolladores del proyecto les quitan las tierras, serán compensados, cómo? ¿Se está considerando el of recimiento de nuevas tierras, dónde?

Frente al tema de la información es fundamental contar con apoyo para revisar los estudios de impacto, prever los efectos futuros, por ejemplo, la contaminación del agua que puede expandirse y afectar una comunidad que vive fuera del área directa del proyecto; o una represa puede frenar a los peces migrantes, modificar la ecología del río, cambiar el nivel freático de las tierras de cultivo, etc., impactando así su fuente de alimentos y subsistencia. Recordar que incluso un proyecto basado u originado en otro país puede impactar en su comunidad. Una mina en otro país puede eliminar sus desechos en un río que fluye a través de su país y del cual su comunidad depende para abastecerse de agua. 
C) Consulta y negociación con la comunidad

17. ¿Qué oportunidades tendrá la comunidad de brindar aportes al diseño del proyecto? ¿Cómo se gestionará esto? 18. ¿Cómo pueden participar las comunidades en el proceso de evaluación ambiental y social?

19. ¿Quién realizará la evaluación ambiental y social? ¿Cuál será el papel del Estado y qué agencia o institución lo supervisará, de manera que se garantice el profesionalismo y la objetividad del mismo?

20. ¿Con quién planea realizar consultas la empresa? ¿Cuál será el papel del Estado a lo largo de la consulta? ¿Qué institución (es) estará a cargo?

21. Según la costumbre en algunas comunidades las consultas se hacen por medio de asambleas en la plaza principal del lugar, convocando abiertamente a toda la población. ¿Es compatible esto con los métodos que la empresa ha considerado? ¿Se garantiza la participación de las mujeres y de personas que pertenezcan a diferentes grupos étnicos?

22. ¿Qué proceso se seguirá para realizar cualquier cambio al diseño del proyecto?

23. ¿Se planifica negociar con las comunidades en cada etapa del proyecto? ¿Se respetarán los mecanismos tradicionales de las comunidades para este efecto?

24. ¿Se informó a las comunidades sobre los impactos ambientales y a la salud?, ¿Qué medidas se han tomado para mitigar estos impactos? 
25. ¿Se abrió o se tiene previsto abrir una of icina donde las comunidades puedan presentar sus quejas e informarse sobre la obra, de manera que pudieran obtener respuestas a sus dudas y temores?

26. ¿Cuáles han sido los criterios para incluir o excluir del proceso de consulta a comunidades?

27. De acuerdo con los riesgos ambientales que han revelado losEIA, ¿cuáles serán los indicadores ambientales de éxito ode cumplimiento de acciones y la metodología para obtenerlos?

28. ¿Cuáles serán las acciones para propiciar la adecuada disposición de residuos sólidos y líquidos generados por las actividades del proyecto? ¿Se cuenta con un plan de acción para involucrar a las poblaciones aledañas en la restauración y preservación de su entorno?

29. ¿Se diseñó algún estudio de impacto social y cultural? ¿Se previó la distribución de estos estudios entre la población afectada? ¿Se garantiza la pertinencia cultural y lingüística del mismo?

Son muchas las preguntas más específicas que surgen frente a situaciones concretas de cada proyecto. Es fundamental que haya vinculación de especialistas de ONG, universidades o institutos de investigación que apoyen a la comunidad en la identificación de normas vigentes que las empresas o los desarrolladores deben respetar, tanto frente a la CCPLI y a los estudios, como a las transacciones de derechos reales, estudios y evaluaciones de diferente orden, etc. 
Paso 3:

Una vez que hayan entrado en contacto con los desarrolladores del proyecto, deben comenzar los líderes y representantes de las comunidades a asegurarse que todas las personas se informen sobre la naturaleza y los impactos del proyecto o iniciativa, promover el involucramiento comunitario y la apropiación de la idea, que lo que se decida se hará con el consentimiento de la mayoría si por alguna razón el consenso no es posible. Luego, los representantes comunitarios pueden negociar con los desarrolladores si la comunidad considera que ese es el siguiente paso a dar.

Es importante tomar en cuenta las visiones de todos los miembros de la comunidad que puedan verse afectados. Hay que asegurarse que en primer lugar las mujeres y los jóvenes, así como miembros de grupos étnicos minoritarios, participen en los procesos de toma de decisiones. Ello porque los proyectos de gran escala afectan en forma diferente a cada uno. Las mujeres por estar a cargo de los cultivos de pan, la comida y el cuidado de los hijos e hijas, están más al tanto de las afectaciones al medio ambiente que suceden o pueden suceder en relación con una obra de gran calado. Con frecuencia son varias las comunidades afectadas por un mismo proyecto. Los desarrolladores del mismo deben informarles de todo acuerdo que hayan celebrado con otras comunidades. Esto, puede ser útil para la comunidad, para 
averiguar si otras comunidades se ven afectadas por la misma obra. También es posible unirse y trabajar junto a ellas para negociar con los desarrolladores del proyecto o el gobierno.

Paso 4:

En una negociación comunitaria con empresas y el Estado, la comunidad tiene derecho a ser informada y consultada y a negociar si lo desea. Hablar con la empresa no significa estar de acuerdo con el proyecto, lo importante es ejercer el derecho de obtener información acerca de algo que afecta la vida de la comunidad y el futuro. Los desarrolladores deben consultar y negociar con la comunidad en busca de obtener un consentimiento libre, previo e informado, desde las primeras etapas de planificación y antes de cada fase nueva del mismo. Ello signif ica que, si están de acuerdo con un aspecto del proyecto en la etapa inicial, el desarrollador necesita continuar y obtener nuevamente el consentimiento en la siguiente fase. Si es factible que ocurra un reasentamiento, los términos y condiciones del mismo deben negociarse con la comunidad, la que tiene el derecho a otorgar o no el consentimiento, antes de tomarse una decisión final.

Por lo general, la construcción de proyectos de desarrollo de gran escala acarrea importantes beneficios financieros para los inversionistas, pero lamentablemente las comunidades locales no siempre obtienen lo que por 
derecholes corresponde, oal menos recibir compensaciones. Todo proyecto puede agregar valor a la comunidad y es posible modificar el nivel de impacto negativo que pueda generar. Es posible acordar a lo largo del proceso de negociación disminuir el impacto sobre la naturaleza y en general sobre el nivel de vida de la comunidad, a la vez que lograr acuerdos sobre, por ejemplo, la creación de mecanismos de participación comunitaria en los beneficios puede resultar útil para que las comunidades afectadas por proyectos accedan a la participación de las utilidades derivadas de los mismos.

Así mismo puede ayudar a la comunidad a elegir qué clase de provecho desea obtener, éste puede enfocarse en mejorar las fuentes de subsistencia, ampliar su territorio, mejorar la inf raestructura o consolidar empleos para sus miembros. Programas de capacitación y de inserción laboral. Construcción de escuelas y clínicas. Derechos especiales de acceso y uso de recursos naturales en las áreas del proyecto para las comunidades afectadas por el mismo. Acuerdos con los desarrolladores del proyecto para delimitar el área de afectación de manera que se proteja parte de las tierras, por ejemplo: áreas de valor cultural o espiritual, sitios sagrados o manantiales.

El desarrollador del proyecto no debe forzarles a iniciar las negociaciones antes de que estén listos para hacerlo. Debe darles suficiente tiempo para considerar la información, decidir cómo desean negociar con los de- 
sarrolladores del proyecto y tomar una decisión como comunidad. No permitir que les impongan limitaciones de tiempo que los coloque en situación de indefensión frente a la arremetida contra la naturaleza o la tierra. Lo que está en juego es muy importante como para permitir constricciones de tiempo.

Si ya comenzó la construcción de un proyecto sin la participación ni el consentimiento de la comunidad, es preciso informar al desarrollador que ésta no es una práctica aceptable desde el punto de vista legal. La comunidad siempre tiene ocasión de expresar su opinión. Es posible que aún puedan frenar la construcción, insistir en que el desarrollador del proyecto sólo pueda proceder si la comunidad puede participar libremente en un proceso donde se acuerden los modos y pasos que hemos identificado en el presente capítulo. Con frecuencia ocurre que en este punto la comunidad busque asesoramiento independiente en materia legal y técnica que les ayude a comprender los efectos del proyecto propuesto. A modo de ejemplo la empresa les informa que usará mercurio, si la comunidad nunca ha oído hablar de este componente, ni sabe mucho acerca de los efectos del mismo, tiene el derecho de solicitar asesoramiento de un experto.

En cuanto a los miembros de cualquier otra comunidad afectada por un proyecto, su participación en las consultas y negociaciones propias del proceso de toma de decisiones debe fundarse en una condición de infor- 
mación plena sobre las cuestiones en discusión y negociación. Es importante no apoyarse únicamente en la información que proporcionan los desarrolladores del proyecto. Es posible que estos intenten presentarlo en forma atractiva a las personas afectadas para lograr su consentimiento. La información obtenida de otras fuentes permite asegurar que la comunidad comprende plenamente el impacto del proyecto en el corto y el largo plazo y los derechos que puede ejercer. Frente a la necesidad de apoyos especializados según la materia de la iniciativa, es importante conseguir asesorías independientes y profesionales, el internet, centros académicos y ONG son medios eficientes para conseguir información que permita encontrar estos apoyos.

Paso 5:

Tomar decisiones como comunidad. La consulta y el consentimiento libre, previo e informado es un derecho colectivo. Por lo tanto, la comunidad debe tomar una decisión en forma conjunta y conforme a los procesos tradicionales de toma de decisiones. Si deciden en favor del proyecto es preciso asegurarse que el acuerdo alcanzado con los desarrolladores del mismo sea registrado por escrito. Este acuerdo es legalmente vinculante.

Si la comunidad da su consentimiento para una iniciativa puede optar por celebrar un acuerdo de im- 
pacto y beneficio (u otro similar) con el desarrollador del proyecto. Es un acuerdo legal que deja constancia del convenio logrado entre la comunidad y la empresa bajo la supervisión del Estado, ${ }^{63}$ incluyendo las condiciones que éste último debe respetar y cuando debe implementarlas o cumplirlas.

Recuerden que en aquellos casos que exigen consentimiento no solo consulta, si la comunidad cree que el proyecto no será positivo, que los efectos negativos pesan más que los beneficios, es posible decir no, en otras palabras negar el consentimiento al mismo. El proyecto sólo debe proceder, en aquellos casos que cumplan las características ya mencionadas, si tanto el gobierno como el desarrollador del proyecto recibieran el consentimiento de las comunidades étnicas en cuestión.

Algunos ejemplos del modo en que los desarrolladores de proyectos pueden dificultar el proceso por medios que riñen con el marco legal, son: a) excluyendo las comunidades de las etapas iníciales de las evaluaciones de impacto; b) forzando las comunidades a firmar acuerdos cuando es claro que éstas no comprenden plenamente los impactos del proyecto, bien que no se ha generado la información que podría responder a dudas

${ }^{63}$ La Corte IDH en la sentencia del pueblo de Sarayaku vs. el Estado de Ecuador, dictaminó que es indispensable la participación del Estado en las consultas, pues es su papel insustituible monitorear los procesos de consulta garantizando la seriedad del proceso y los acuerdos que se logren. En el mismo sentido se expresó la Corte de Constitucionalidad de Guatemala sobre el carácter no vinculante de las consultas hechas por los indígenas mismos, por no contar con la presencia del Estado. 
en este sentido o por que la negociación o el diálogo se ha dado únicamente con algunos pocos que quizás no representen la visión de toda la comunidad; c) negociar con sectores de la comunidad otorgando favores que niegan a otros, de esta manera dividen la población, debilitando la contraparte. Otro mecanismo puede ser la firma de convenios privados con algunos miembros de la comunidad sin tomar en cuenta el conjunto de la misma. Es importante involucrar al Estado y exigir que estos mecanismos que constituyen expresiones de mala fe, sean debidamente documentados para ser adecuadamente utilizados en litigios a que se podría dar lugar.

Solicitar la asistencia de agencias o instituciones independientes en el monitoreo puede ayudar a convencer a los desarrolladores del proyecto que las inquietudes en cuanto al impacto y los compromisos son auténticas y legítimas.

Paso 6:

La consulta es un proceso continuo. Los proyectos de desarrollo de gran escala necesitan varios años de planificación antes de comenzar, y luego impactan en la comunidad durante varios años, generaciones o de manera definitiva. El desarrollador del mismo debe asegurarse de que la comunidad sea informada regularmente sobre su progreso, la comunidad debe tener la posibilidad de hacer preguntas y plantear sus inquietudes. 
El derecho a la consulta de la comunidad debe respetarse a lo largo de todo el proceso. Su objetivo es resaltar la importancia de la comprensión de las diferentes actividades que pueden tener lugar en cada etapa de la iniciativa, y lo que los desarrolladores de proyectos deben hacer para involucrar las comunidades en cada una de las etapas.

Es importante recordar que no sólo proyectos u obras dan lugar a este derecho, también iniciativas legislativas o políticas públicas que puedan afectar derechos de pueblos indígenas o tribales.

Los representantes comunitarios tienen que monitorear el desarrollo del proyecto mientras éste avanza. Para la comunidad, es importante mantener registro del cumplimiento de los compromisos asumidos por parte de la empresa y el gobierno. Una forma de hacerlo consiste en negociar condiciones o resultados específicos del proyecto, que deben constar por escrito y tener plazos asignados para su cumplimiento. Es posible que el desarrollador del proyecto cambie a lo largo del ciclo del mismo. En este caso, el nuevo desarrollador del proyecto debe respetar los compromisos asumidos por el anterior. Esta es una de las razones por las cuales es importante la presencia del Estado y documentar por escrito la decisión comunitaria sobre el proyecto y los beneficios negociados. También es posible negociar mejores beneficios para la comunidad con el nuevo desarrollador del proyecto. 
Una posibilidad es que la comunidad establezca un foro permanente integrado por la comunidad y el desarrollador del proyecto, a fin de mantener una comunicación regular y continua. También podrá usarse este foro para tratar las preocupaciones o los reclamos que surjan en la comunidad durante la operación del proyecto, si el mismo prosigue. ¿Dónde se podrá obtener apoyo y más información? ¿Quién más trabaja en el tema de los recursos naturales? ¿Qué puede hacer la comunidad si el gobierno o el desarrollador del proyecto la ignora?

Aunque intenten seguir estos pasos, es posible que los desarrolladores del proyecto los ignoren y continúen implementándolo. Entonces, la comunidad puede optar por desarrollar una estrategia de defensa y promoción de sus derechos en función de las circunstancias e intereses propios y que puede incluir protestas comunitarias, la resistencia pacífica y la sensibilización del público a través de los medios y las ONG locales e internacionales y preparar y armar el caso para llevarlos a los tribunales. 



\section{PARTE II}

\section{Consulta: \\ ¿Qué información es básica para tomar decisiones?}

\section{NemesioJ. Rodríguez \\ PUIC-UNAM \\ Oficina Oaxaca}

\section{Introducción}

Consulta e información

Si hay un tema controvertido, entre otros, referido a los pueblos indios y sus territorios es el de la Consulta y, como parte fundamental de la misma, la información que se le proporciona a los sujetos consultados para su toma de decisiones. Y es de importancia crucial debido a que incluye al presente y el futuro inmediato (30 a 50 años; una o dos generaciones) de los pueblos involucrados. Es por esto que se requiere la aplicación del principio de máxima transparencia del proceso de transferencia de información proporcionada para que la relación empresa-proyecto con el pueblo indio territorialmente ubicado, con la mediación estatal, sea equitativa. En este sentido, el primer acto de cualquier consulta tiene que ser el de la 
elección tripartita (pueblo indio, empresa-proyecto e institución pública sectorial) de la instancia o institución garante, tanto del proceso como de la información necesaria. Teniendo en cuenta que cada proceso de consulta, además de específico, tiene que ser construido en cada caso, en la situación incontrovertible en que se ponen en juego dos epistemologías y dos visiones del mundo (empresa y pueblo indio) no siempre compatibles.

Si se toma como principio de respeto y gobernabilidad la consulta, se tiene que a más consulta menor conflictividad social, siempre y cuando sus resultados sean garantizados, ya sean estos el sí y sus cómos o el no simple y llano. Los proyectos se proponen para realizarse en un espacio concreto, es decir que tienen una ubicación geográfica específica en una región delimitada. No es sólo un punto en el mapa; incluye fauna, flora, suelo, subsuelo, cuencas, microcuencas, nacimientos de agua, lagunas, pantanos, régimen de lluvias, sistemas altitudinales (montañas, valles, mesetas), temperaturas estacionales $y$, fundamentalmente, población humana. Es decir que los proyectos no sólo se relacionan con la naturaleza sino que, también, con un colectivo social portador y creador de cultura, que tiene una dinámica propia de población organizada para interactuar prof undamente con esa naturaleza para su sobrevivencia a partir de una experiencia histórica local y con una ritualidad sobre el medio que practica cotidianamente. Cualquier proyecto sobre 
esta naturaleza culturalizada transforma ambiente y sociedad. Es decir que el territorio es, para una comunidad, un patrimonio histórico creado tanto tangible como intangible, es decir biocultural. Biocultural en tanto es un espacio donde la comunidad ejerce sus conocimientos, lo interpreta y deposita sistemas simbólicos y creencias a través de mitos y rituales.

Lo anterior es lo que determina que el proceso de Consulta deba construirse en cada espacio de acuerdo con la(s) sociedad(es) involucrada(s), su(s) cultura(s), su(s) lengua(s), su(s) economía(s), su(s) patrimonio(s) tangible(s) e intangible(s), su(s) creencia(s) y su(s) espiritualidad(es) con territorio(s) y territorialidad(es) propia(s). Es decir, no es algo que se puede normar desde una legislación, salvo las garantías básicas, ya que se trata de un procedimiento básico que tendrá lugar en diferentes ambientes habitados, construidos e interpretados por culturas diversas; y estos son los sujetos de la Consulta.

\section{Información Básica Necesaria}

La Suprema Corte de Justicia de la Nación (SCJN) estableció para proyectos de desarrollo e inf raestructura que, en los mismos, el derecho a la información de los pueblos es ineludible para las empresas y que la misma debe ser: oportuna "durante las etapas de diseño, ejecución y evaluación de planes, proyectos o medidas que puedan 
afectar los territorios tradicionales de las personas o pueblos"; accesible y suficiente "[...]. La naturaleza, envergadura, ritmo, reversibilidad y alcance [...]. La razón o las razones o el objeto del proyecto y/o la actividad. La duración [...]. La ubicación de las áreas que se verán afectadas. Una evaluación preliminar de los probables impactos económicos, sociales, culturales y ambientales; incluso los posibles riesgos, y una distribución de be-neficios justa y equitativa en un contexto que respete el principio de precaución [...]".64

Ante cualquier proyecto planteado el colectivo local debe solicitar información que se aplica en general para todos los tipos de proyectos (minería, forestal, energía, inmobiliarios, centros comerciales, turísticos, escalas náuticas, pesqueros, rellenos sanitarios, centros de manejo de residuos tóxicos, compra o venta masiva de terrenos, utilización de transgénicos, corredores industriales, carreteros, puertos, aeropuertos, ferrocarriles, plantas de generación de energía geotérmica, nuclear, hidroeléctricas y proyectos eólicos, entre otros). Información que responda a preguntas como:

¿Qué inversión en conocimiento, tecnología e innovación hay en la propuesta de proyecto?

¿Qué inversión tiene la propuesta de proyecto para la

64 Suprema Corte de Justicia de la Nación. "Protocolo de Actuación para quienes imparten justicia en casos relacionados con proyectos de desarrollo e inf raestructura". México D.F., 2014, p. 78. Disponible en: <www.supremacorte.gob.mx> 
reducción de la desigualdad regional y local?

¿Qué medidas tiene la propuesta de proyecto para evitar la exclusión social?

¿Qué promoción y proyección de dinámicas productivas locales tiene la propuesta de proyecto para generar valor agregado?

¿Qué propone el proyecto para los proveedores de bienes y servicios?

¿Qué contiene la propuesta de proyecto sobre la cantidad y calidad de empleo (empleos genuinos) para la población local?

¿Qué acciones promueve la propuesta de proyecto sobre la seguridad alimentaria, la salud y nutrición local y regional? ¿Qué prevenciones tiene la propuesta de proyecto sobre los impactos del cambio climático?

¿Se ajusta el proyecto a las capacidades del ecosistema local y regional?

¿Qué prevé la propuesta de proyecto para los gastos por pérdida de capital natural, contaminación y desplazamiento de población?

¿En la propuestade proyectoen la relación costo-beneficio se incluye o no los costos sociales y ambientales?

¿En la propuesta de proyecto se formula la redelimitación de áreas protegidas locales para poder realizarlo? ¿La propuesta de proyecto contiene o no la promoción y realización de un ordenamiento territorial y su plan de manejo local? 
¿Hay o no evidencias de vestigios arqueológicos, paleontológicos y lugares de rituales o de territorios sagrados?

¿La tecnología que utilizará el proyecto es la más adecuada ambiental y socialmente?

¿Cómo se garantizará el cumplimiento de los compromisos contraídos?

Para poder reflexionar sobre los contenidos de las respuestas a las anteriores preguntas, la comunidad local debe tomar en cuenta algunas consecuencias, entre otras:

- Los impactos negativos de un proyecto pueden ser controlados, mitigados, compensados pero no pueden ser ignorados ni anulados.

- Hay que revisar las relaciones entre los riesgos e impactos con los beneficios posibles.

- Si la tecnología que utilizará el proyecto es elegida exclusivamente por la relación costo-beneficio, la misma no será adecuada ambientalmente.

- Si la propuesta tiene que ver con la creación de parques nacionales y reservas ambientales realizadas desde fuera del control poblacional local, hay que tener en cuenta que son vehículos de pérdida territorial para la comunidad debido a que su administración pasa a personal elegido externamente.

- Si el proyecto es comunitariamente aceptado es importante establecer en el mismo, frente a eventualidades de su suspensión o fracaso, un Fondo de Garantía 
en Fideicomiso en el cual los sujetos sociales tengan voto de calidad para su utilización.

Hay que tener en cuenta que las reuniones informativas no cubren el Consentimiento Previo, Libre e Informado y culturalmente adecuado. La información debe ser amplia y de calidad para que permita comprender en toda su amplitud las ventajas y problemas que presentan a una comunidad local una propuesta de proyecto. La información completa y necesaria para tomar decisiones comunitarias no puede ser transferida en una asamblea de un día y su maduración debe darse en tiempo suficiente de acuerdo a la temporalidad local. La información puesta a disposición de la comunidad por la empresaproyecto, por las instituciones estatales sectoriales, tiene que ser complementada con información de la propia comunidad y, en caso necesario, recurrir a especialistas en el tema de que se trate (universitarios, ONG'S, etc.).

La construcción de Bancos de Datos sobre Megaproyectos en Zonas Indígenas y Negras de América Latina en el PUIC-UNAM ${ }^{65}$ nos permite construir sistemas

65 Mezinal es un proyecto del PUIC-UNAM en proceso que, hasta ahora, cuenta con los siguientes Bancos de Datos que se actualizan periódicamente: 50 años de movimientos indígenas en América Latina <http://www.nacionmulticultural.unam.mx/ movimientosindigenas/>; Empresas Eoloeléctricas y Población Local de América Latina <http://www.nacionmulticultural.unam.mx/mezinal/eoloelectricas/>; Megaproyectos Mineros en Zonas Indígenas y Negras de América Latina <http://www. nacionmulticultural.unam.mx/mezinal/mineria/>; Agua en Territorios de Indios y Negros de América Latina <http://www.nacionmulticultural.unam.mx/mezinal/ hidrologicos/>; Impactos en Selvas, Bosques y Manglares en Territorios Indígenas y Negros de América Latina <http://www.nacionmulticultural.unam.mx/mezinal/ forestal/>; Infraestructura Estratégica en Zonas Indígenas y Negras de América Latina (Carreteras, Puertos y Ferrocarriles) <http://www.nacionmulticultural.unam.mx/ 
básicos de preguntas específicas, que las comunidades deben hacer a los responsables de los proyectos que se plantean en algunos de los distintitos temas. En el entendido de que la calidad de la información que posea a la comunidad, sobre un proyecto que le atañe, posibilitará establecer la relación entre beneficios prometidos y las afectaciones posibles y tomar las decisiones que más les convenga. Se debe solicitar que la información proporcionada, en los casos que sea posible, esté ubicada en mapas georeferenciados a la menor escala accesible, preferentemente de 1:50.000.

\section{Información temática: algunos ejemplos}

\section{1) Minería}

Además de las preguntas generales que se encuentran en la introducción hay que solicitar información sobre los siguientes aspectos.

Los proyectos mineros tienen, en general, cinco etapas: prospección; exploración; factibilidad; explotación y beneficio. Prospección: no requiere permisos y se toman muestras de piedras en recorridos en superficie.

Exploración: se hacen perforaciones a diferentes prof undidades y se toman muestras en grandes cantidades.

\footnotetext{
mezinal/capufe/>; Empresas Indígenas y Populares <http://www.nacionmulticultural.unam.mx/empresasindigenas/>; Catálogo de Videos <http://www.nacionmulticultural.unam.mx/catalogovideos/>; Pueblos Negros de América Latina <http:// www.nacionmulticultural.unam.mx/reconocimientopueblosnegros/>
} 
Factibilidad: se determina por la relación entre inversión y ganancia por la venta de los minerales, a lo cual se le agrega la disponibilidad de energía eléctrica, de fuentes de agua y los caminos de acceso.

Explotación: extracción de grandes volúmenes de rocas con minerales en dos modalidades básicas: de socavón o túneles interiores; y de tajo abierto o cielo abierto a partir de destruir y desmoronar los cerros totalmente.

Beneficio: separación de los minerales de las rocas con insumos tóxicos (cianuro, mercurio, etc.) y fundición de los minerales convirtiéndolos en lingotes o barras.

Si bien hay que disponer de información de cada una de las etapas anteriores, hay que prestar especial atención en las últimas tres. Si el proyecto es de minería a cielo abierto, por ejemplo, para obtener una tonelada de mineral (oro) se utiliza $1 \mathrm{~m}^{3}$ de agua por segundo; es decir unos 31.5 millones de $\mathrm{m}^{3}$ de agua anuales más la energía necesaria. ¿Hay localmente esa cantidad de agua disponible sin competir con la utilizada para consumo humano, agrícola y ganadero local? Además, hay que tener en cuenta que el agua utilizada en la minería no puede volver al río o arroyo porque son aguas ácidas por residuos tóxicos como el cianuro de sodio y metales pesados. Estas aguas y lodos tóxicos deben ser contenidos en lagunas exprofeso. Por otro lado, hay que disponer de información sobre los nacimientos, ojos de agua, manantiales que serán destruidos con el desmoronamiento de los ce- 
rros. Por otro lado es necesario contar con informaciones muy precisas sobre las medidas que tiene el proyecto sobre su proceso de cierre y la estabilización de desechos, ya que éstos son un peligro latente por años.

En cada una de las etapas se debe contar con información sobre los empleos permanentes y temporales que utilizará el proyecto minero y si la cantidad y calidad de los mismos puede, total o parcialmente, ser cubierta por la población local. Hay que tener en cuenta que el personal externo será mayoritariamente masculino con disponibilidad de dinero y que vivirá en un campamento minero con necesidades sociales y alimenticias extra comunitarias con lo cual se encarecen los productos alimenticios y crece el consumo de alcohol y la trata de personas en forma de prostitución.

Cuando la minería es a cielo abierto, al derrumbar los cerros se está destruyendo el simbolismo territorial que la cultura local les da y, por lo tanto, se afecta su patrimonio intangible.

Los relaves mineros implican transporte, almacenamiento y uso inseguro de insumos tóxicos.

2) Recursos Hídricos

Los temas fundamentales sobre los que hay que solicitar información son los que siguen.

Los grandes proyectos de utilización de agua se 
pueden agrupar en cuatro tipos: aguas superficiales, energéticas, aguas subterráneas y desvíos de ríos.

Aguas superficiales: construcción de bordos o presas para riego y/o control de avenidas de agua a planicies, básicamente costeras. ¿Bloquearán o no el curso aguas abajo de la cortina? Si éste es bloqueado o disminuido significativamente destruirá aguas abajo los humedales y desertificará zonas completas afectando la biodiversidad y las economías locales.

Presas hidroeléctricas: además de lo anotado en aguas superficiales estas son obras de gran magnitud e implican desplazamiento de población e inundación de tierras productivas, recreativas, turísticas, deportivas, paisajísticas y ecosistémicas y afectación a la pesca ribereña. Por otro lado se forman lodos putrefactos en los embalses que contaminan cursos de agua. Este conjunto de impactos suelen resultar en un despojo de tierras a comunidades y producen un cambio en el uso del suelo.

Extracción de aguas subterráneas: se refiere al bombeo para fines industriales y por los volúmenes de extracción se genera la desaparición de manantiales y nacimientos de agua, se aumenta la prof undidad de los mantos freáticos, se disminuye el agua de los pozos caseros para uso familiar y sostén de solares y hay menor disposición de agua para las actividades agrícolas y ganaderas. Cuando los parques industriales se instalan en zonas de humedales los residuos tóxicos contaminan los cursos de agua 
y los esteros, la fauna se muere o migra, hay daños a la salud comunitaria y las economías agrícolas locales se deterioran por riego con aguas contaminadas.

Desvíos de ríos: estos se dan con el propósito de dar agua a parques industriales, complejos turísticos y centros urbanos de crecimiento explosivo. Esto lleva a un cambio drástico de uso del suelo, la desertificación del mismo y una transformación del paisaje impactando el complejo socio-cultural y económico de las poblaciones ribereñas.

La tala forestal masiva en cuencas y microcuencas hidrológicas producen inundaciones de gran magnitud con el arrastre creciente de sedimentos sobre las lagunas costeras, los cuales forman barreras que impiden el desagote y renovación de las lagunas.

Los rellenos sanitarios son otros de los contaminantes de los cursos de agua y de los mantos freáticos.

Los proyectos que impliquen agua deben especificar su uso diferencial en residencial (turismo y centros habitacionales), comercial (embotelladoras y fábricas de hielo) e industrial (plantaciones, siderurgia, minería) y sus impactos sobre el uso local del agua. También deben informar sobre el equipamiento y tecnología en bienes y servicios, la contaminación del recurso, la vulnerabilidad ante catástrofes, la propagación de plagas y enfermedades y la prevención de uso en incendios, etc.

Derrames petroleros y de hidrocarburos grandes contaminantes de cursos de agua iqué sistemas de vigi- 
lancia, prevención y control de derrames?

Salinización de tierras por irrigación, por inundación más pesticidas y fertilizantes con nutrientes excesivos en las aguas (nitrógeno, p.e.). Contaminación con sustancias tóxicas (mercurio, cianuro, dioxinas, antibióticos en animales) y no biodegradables (plásticos).

Manglares: se encuentran en estuarios y zonas costeras con agua salada cercanas a cursos de agua dulce. Tienen gran tolerancia a la salinidad, sus raíces aéreas estabilizan los suelos y sus semillas son flotantes. Es el hábitat de las formas juveniles de peces, moluscos y crustáceos, además de proporcionar anidamiento a aves y reptiles, ofreciendo alimentación y protección a todas estas especies. A su vez son filtros de sedimentos y nutrientes orgánicos protegiendo el litoral contra la erosión costera marítima y del viento de ciclones y huracanes. Por cada mangle destruido se pierden 767 kgs. de especies marítimas comerciales. Las granjas camaronícolas industriales deforestan el manglar y luego de 5 años abandonan el lugar dejando la tierra inservible por el caldo tóxico con químicos de los alimentos industriales y los antibióticos que les dan a los camarones. ¿Cómo se plantea el proyecto prevenir, vigilar y mitigar sus efectos?

\section{3) Turismo}

Algunos temas y preguntas que deben sustentar la información sobre proyectos turísticos y dimensionen su impacto. 
El turismo implica la transformación de los espacios sociocomunitarios y la alteración de patrones de asentamiento humano. El gran turismo implica la apropiación y privatización de tierras costeras, desplazamiento de población e impacto ambiental. Los megaproyectos turísticos involucran sistemas complejos de inf raestructura: proyectos inmobiliarios, edificios administrativos, unidades habitacionales, centros de convenciones, campos de golf, centros de consumo -grandes tiendas-, escalas marítimas o marinas, rellenos sanitarios, apertura de caminos y calles, puentes y aeropuertos. Los muelles turísticos en zonas de manglares se hacen con base en un relleno de grava y arena, sostenidas por bloques de cemento que afectan la supervivencia del manglar y las especies útiles a las comunidades locales que en él viven. Es decir que hay una alteración de la línea costera con alta concentración de la densidad de construcción. El auge inmobiliario lleva la especulación que distorsiona el valor de los terrenos. Esta especulación lleva a una redistribución espacial de los habitantes locales ubicándolos en los lugares de menor valor comercial y escénico; es decir que produce una asimetría espacial en detrimento de la comunidad local. ¿Cómo contempla el proyecto proteger el medio y la participación de la población local en el desarrollo del mismo?

Paralelo a este turismo de gran escala hay otras variantes que se están imponiendo en zonas de territo- 
rios indígenas como el turismo "naturalista": ecoturismo, de aventura, agroturismo, agroecoturismo, científico, ictioturismo o pesca deportiva, entre otros. Proyectos que se plantean a las comunidades locales como beneficiosos, con construcción con materiales locales y armónicos con el paisaje del entorno. Estos proyectos de turismo "naturalista" impulsados mayoritariamente por instituciones gubernamentales y empresas privadas deben sustentarse, frente a la comunidad con informaciones precisas. Por ejemplo, el acceso al territorio; ¿garantiza calidad de vida y genera oportunidades al conjunto de la sociedad local? Si es así, ¿cómo lo hará el proyecto en el corto, mediano y largo plazo?; la afluencia turística esperada ¿cómo se regula con criterios de capacidad de carga local, en términos de uso de energía, agua, alimentación, basura, aguas negras, etc.?; ¿el proyecto integra o no los conocimientos locales sobre su medio?; ¿cómo apoya el proyecto el ordenamiento territorial?; ;en manos de quién quedará el transporte terrestre, la provisión de alimentos y bebidas?; ¿cómo participará la comunidad en la administración del proyecto?; ¿qué empleos, con qué salarios y en qué actividades participa la población local?; iquién será el propietario de los inventarios de recursos ambientales y culturales sobre los cuales se of rece el atractivo turístico?; ¿la oferta turística del proyecto está dirigida a turismo doméstico regional, nacional o internacional?; ¿qué nivel de capacitación recibirá la comunidad para 
participar en el proyecto?; ¿a quién corresponde la instalación y manejo de tirolesas, carruajes, botes y canoas y quiénes serán sus guías?; el mantenimiento de cabañas y equipos ¿a quién corresponde?; ¿cómo entran en el proyecto las artesanías y manifestaciones culturales locales?; ¿se contempla la creación de zoocriaderos y viveros en el proyecto?

\section{4) Forestal}

Los proyectos forestales que se presentan a los pueblos indios, además de las preguntas generales ya planteadas, tienen que informar sobre un conjunto de otros aspectos. Y esto ya que los bosques y selvas, además de los servicios ecosistémicos y paisajísticos, son parte integrante de los patrimonios tangibles e intangibles de los diferentes pueblos que los habitan. Los bosques y selvas constituyen parte importante de su bienestar sociocultural y ritual, además de controlar la erosión, permitir la polinización, generar las condiciones de reproducción de flora y fauna local. A su vez los bosques y selvas aseguran la viabilidad socioeconómica de las comunidades indias, al asegurarles productos maderables para su vivienda, agua, seguridad alimentaria y su diversidad, plantas para medicina tradicional y leña.

Si el proyecto es de explotación forestal la información básica necesaria tiene que responder a preguntas del tipo siguiente: iel proyecto contempla y respeta 
el manejo forestal consuetudinario local y regional?; ;el proyecto tiene en cuenta los usos múltiples del bosque por la comunidad tanto sociales, culturales y económicos como los espirituales, medicinales y ambientales? y si sí, ¿cómo?; ¿el proyecto se propone el fortalecimiento de capacidades locales en materia forestal? y si sí ¿cómo?; ¿el proyecto contempla sistemas de vigilancia para evitar saqueo, plagas y prevenir incendios? y si sí ¿en manos de la comunidad o en agentes externos?; ;el proyecto se plantea el amortiguamiento y la protección de las cuencas, microcuencas y nacimientos de agua? y si sí ¿cómo?; ¿el proyecto propone la instalación de aserraderos fijos o móviles? y ¿con qué tecnología?; ¿el proyecto propone el estufado de la madera? y si sí ¿con que tecnología y energía?; ¿el proyecto plantea la creación de viveros para la reforestación? y si sí ¿con qué tecnología?; ¿en el proyecto se plantea la participación de la comunidad en la administración y en qué niveles?; ¿ en el proyecto se plantea sólo la extracción de madera o también la posibilidad de valor agregado en su transformación (triplay, carpinterías, muebles, juguetes, etc.)?; ¿cómo se plantea en el proyecto el manejo de los rodales?; ¿cómo se plantea en el proyecto el diseño y apertura de los caminos forestales?; ¿qué capacitación y apoyos técnicos tendrá la comunidad con el proyecto forestal?

Si el proyecto es de plantación forestal los requerimientos de información son otros. Y hay que tener 
en cuenta que las plantaciones no son bosques ya que estos son sistemas biológicos complejos y aquellas reducen al mínimo la diversidad. Las plantaciones forestales comenzaron como medio de producir celulosa y papel y, ahora, se agregaron al abanico de agro-combustibles. En los últimos 20 años creció la producción de etanol y aceite derivados de vegetales a través de monocultivos a gran escala (maíz, soja, caña de azúcar, palma africana y jatropha). A los anteriores se les sumó, últimamente, el de generación de energía utilizando biomasa de madera. Al principio se planteó como reciclaje de aserríos, pero ha derivado en la utilización de árboles completos. Árboles provenientes de plantaciones de monocultivos forestales. Esta modalidad se impone sobre territorios aptos para la producción de alimentos de las comunidades locales y regionales. Hay que tener en cuenta que es una producción forestal para la exportación y generación de energía en el norte global.

Las preguntas básicas a las que deben responder con información clara y verificable un proyecto monocultivo forestal son, entre otras, las siguientes: ¿el proyecto propuesto es sobre territorios aptos para la producción de alimentos de las comunidades regionales?; ¿el proyecto, al impactar sobre territorio útil, desplazará población local?; ¿el proyecto requerirá deforestar bosque primario y secundario de las comunidades?; ;el proyecto, al sustituir ecosistemas locales, como mitigará sus efectos?; ¿el 
proyecto cómo evitará el acaparamiento de tierras para formar una unidad de producción continua? o ¿respetará la discontinuidad de los territorios de labor de los pueblos indios?; ¿el proyecto tiene en cuenta las necesidades de abastecimiento de agua de la población local, ya que las plantaciones forestales consumen entre el 20 y el 30 \% más de agua por día?; ¿cómo se planteó el proyecto evitar la erosión y salinización del suelo por el uso excesivo de agua y agrotóxicos?; ¿cómo evitará el proyecto la contaminación de los cursos de agua con herbicidas?; ¿utilizará el proyecto variedades forestales modificadas genéticamente?; ¿qué impactos contempla el proyecto, sobre los polinizadores locales (abejas, murciélagos, pájaros, insectos)? y iqué medidas de mitigación?

Si el proyecto se basa en los contenidos del programa internacional REED+ (Reducción de Emisiones por Deforestación y Degradación de los Bosques) las comunidades consultadas tienen que solicitar información sobre distintos temas alrededor del cambio climático y su articulación con la agricultura y la ganadería que REED+ no relaciona y oculta. El objetivo de REED+ es el de aumentar la captura de carbono por manejo sustentable de bosques y selvas y su conservación en países con cubierta vegetal que recibe dinero a cambio de los bonos de carbono. Esto último es un derecho a la contaminación que adquieren, por un precio, empresas contaminadoras que utilizan combustibles fósiles y, ahora, 
bioenergéticos. Mismas que, a su vez, son las que promocionan, controlan y comercian con monocultivos extensivos (mayoritariamente transgénicos) de soja, maíz, caña de azúcar, palma af ricana y pasturas para ganado y ganaderización, sobre todo del trópico. Estas actividades agrícologanaderas son las responsables entre el 70 y 90 \% de la deforestación global. Este proceso afecta profundamente los sistemas combinados de producción de alimentos de los pueblos indios. Por un lado hay gran presión sobre sus tierras productivas para instalar megaproyectos de monocultivos industriales, que aumenta la presión sobre los bosques. Y lo anterior se ataca por el lado de establecer restricciones a las poblaciones locales sobre su uso social, cultural, económico y espiritual de los bosques y selvas y prometerles pagos exagerados y que no se pueden cumplir por no tocar la masa forestal, y perder control sobre parte o la totalidad de su territorio.

En este caso el proyecto debería informar sobre: ¿reconoce y protege los derechos colectivos de la población local sobre sus tierras, territorios y recurso? y si sí ¿cómo?; ¿incluye la protección y promoción de los medios tradicionales eficaces en la producción de alimentos y el manejo forestal consuetudinario de la población local? y si sí ¿cómo?; ¿respeta el sistema local de autoridades y autonomía y la toma de decisiones colectivas?; ¿tiene la población local representación adecuada y equita- 
tiva en los órganos y procesos de toma de decisiones del proyecto? y si sí ¿cómo?; ¡si la distribución de beneficios es equitativa y por acuerdos tomados colectivamente? y si sí ¿cómo?; ¿cuenta con el diseño de un sistema de control legal para que la comunidad pueda defender sus derechos?, y si sí ¿cómo?

5) Energía con base en recursos naturales renovables

El impulso actual a la generación de energía a partir de utilizar recursos naturales renovables como el viento, el sol y el agua lleva a la búsqueda de utilizar territorios en manos de pueblos indios, para su operación, mismos que tienen disponibilidad de recursos. En este apartado no tocaremos los que se realizan con base en el agua (presas hidroeléctricas, mareas, geotermia, etc.) ya que algunos han sido vistos anteriormente.

En el caso de los proyectos eólicos o eoloeléctricos su transcurso tiene varios componentes que, en general, son los siguientes: medición del potencial del viento en una región; acuerdos con los dueños de la tierra; diseño del proyecto, construcción; operación del parque; e infraestructura para conducción de energía.

La medición del viento se realiza a partir de equipos computarizados que registran diariamente la fuerza del viento, su direccionalidad, su humedad relativa. Su duración va de un año a año y medio, según los casos. Los 
equipos de medición se instalan en territorios ejidales y comunales a cambio de un permiso de exploración y un pago de renta del espacio a ocupar. Si estas mediciones justifican la formulación de un proyecto eólico con potencial de negocios se entra en la segunda etapa con dos componentes paralelos: acuerdo con los dueños de la tierra y diseño del proyecto. Los acuerdos con los dueños de la tierra se realizan en dos niveles; por un lado con el colectivo ejidal o comunal en tanto tenencia colectiva de la tierra y, por el otro, con los poseedores concretos de los terrenos a los cuales se les paga una renta, bajo contrato, hasta que se realice el proyecto. El diseño del proyecto se toma como una acción técnica por fuera del colectivo poseedor del territorio. El diseño del proyecto sirve para la búsqueda de financiamientos bancarios, la obtención de los permisos requeridos (nacionales, estatales y municipales) y la organización de los estudios de impactos ambientales y sociales. Financiamientos asegurados y permisos obtenidos dan pie a la etapa de construcción. Esta implica el trazado y construcción de caminos de acceso e internos del parque eólico, la cimentación e interconexión subterránea de las torres, la instalación de las torres y las turbinas con sus respectivas aspas. Etapa que implica desde la contratación temporal de mano de obra no calificada, acarreo y transporte de materiales, limpieza de terrenos, bodegas y personal calificado para las conexiones de turbinas y red de energía. Y 
la construcción de un cuarto de control del parque. Para entrar en la operación del parque se requiere del trazado y construcción de líneas de transmisión de energía a una subestación desde la cual se redistribuye la energía conectándola con la red eléctrica nacional. Con el parque en operación los contratos con los poseedores de los terrenos rentados cambian sus contenidos monetarios, ya que la empresa paga, además de la renta, un porcentaje por generación, más afectaciones y la instalación de torres en los terrenos según diseño técnico.

La población local debe contar con información proporcionada por la empresa y el gobierno federal contestando y aclarando preguntas sobre temas como los siguientes, entre otros:

¿El proyecto contempla la utilización tradicional agrícola y ganadera de la tierra que ocupa el parque eólico?, y si sí ¿cómo?; ¿el proyecto está técnicamente diseñado para evitar daños a la fauna local, sobre todo un polinizador como los murciélagos?, si sí ¿cómo?; ¿el proyecto en su diseño protege los cursos normales de las aguas superficiales? y si sí ¿cómo?; iel proyecto contempla que las líneas aéreas de transmisión en interconexión en su trazado no afecten a la masa forestal local? y si sí ¿cómo?; iel proyecto contempla la utilización de aceites biodegradables en sus turbinas?; ;el proyecto contempla mitigar los impactos ambientales negativos, ruido, contaminación visual, afectación de 
rutas migratorias de aves, etc.? y si sí ¿cómo?; ¿el proyecto contempla la capacitación técnica de población local para su integración en empleo permanente? y si sí ¿cómo?; ¿el proyecto contempla evitar el aumento de la desigualdad en la población local-regional? y si sí ¿cómo?; ¿el proyecto cuenta con una estrategia para evitar la fragmentación comunitaria entre los que tienen tierras en renta y los que no las poseen? y si sí ¿cómo?; ¡el proyecto se articula con el municipio y agencia municipal para obras y acciones de benef icio social comunitario? y si sí ¿cómo?; ¿el proyecto se relaciona con la población a través de los que tienen tierra contratada de manera individual o con asambleas de ejidatarios y comuneros y asambleas de pobladores?; ien la administración del parque tienen los pobladores alguna participación? y sisí ¿cómo?; ¿la vigilancia del parqueeólico está en manos de la comunidad o es externa?; ¡el reparto de beneficios está dentro de los estándares internacionales?; ¿en caso de fracaso o abandono del proyecto por situación económica o cambio climático con redireccionalidad espacial de los vientos qué pasa con la inf raestructura instalada?; ¿el proyecto cuenta con un Fondo de Garantía para cubrir eventualidades? y si sí ¿cómo opera?; ¿ participa o no la comunidad local en la administración del mismo? 


\section{A manera de conclusión}

Los pocos ejemplos anteriores deben ser tomados como lo que son, es decir, ejemplos que podríamos ampliar temáticamente como actividades que realiza una colectividad humana (comercio, transporte, infraestructura, educación, salud, arqueología y paleontología, pesca lagunaria y ribereña, artesanías, caza sinergética, fracking, etc.). Es decir que las comunidades locales que se enfrentan a un proceso de consulta, que es su derecho, también tienen que ejercer el derecho a la información para poder decidir con pleno conocimiento de causa sobre cualquier proyecto y los impactos del mismo sobre su presente y su futuro inmediato. No se trata que sólo se proporcione información sobre los beneficios, estos deben estar acompañados de los problemas que implica el obtener beneficios cuando se altera el medio ambiente y las relaciones socioculturales al interior de los pueblos indios y de estos con su entorno. Los qué, cómo, cuándo, dónde y por qué de cada proyecto y de cada uno de sus componentes sobre la vida cotidiana en todas sus dimensiones son las preguntas cuyas respuestas nos deben guiar para decidir ¿qué hacer? y equilibrar los sí y los no, colectivamente, sustento de la vida social. 

Consulta, territorios indios e información. Manual de uso múltiple, editado por el Programa Universitario de Estudios de la Diversidad Cultural y la Interculturalidad, unAM, se terminó de imprimir el día 20 de marzo de 2016 en los talleres de Gráfica Premier, S.A. de C.V., 5 de febrero 2309, Col. San Jerónimo Chicahualco, C.P. 52170, Metepec, Estado de México. Para su composición se usó el tipo Berkeley Oldstyle de 12.5 puntos. El tiro consta de 500 ejemplares impresos en offset, interiores en papel bond de 90 grs. y forros en cartulina sulfatada de 14 puntos. Cuidado editorial: Juan Mario Pérez Martínez, con la asistencia de Mara Ivonne Marcial Urbano y Raúl Paez de la Cruz. Formación editorial: L.D.G. Gabriela Lavín. 

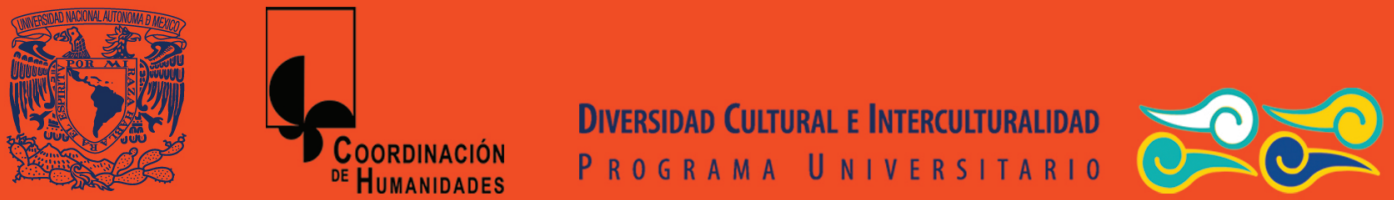